\title{
The Importance of the Internal Information Environment for Tax Avoidance
}

\author{
John Gallemore \\ gallemore@unc.edu \\ Eva Labro* \\ Eva_Labro@unc.edu \\ University of North Carolina at Chapel Hill
}

January 2013

Comments welcome

Corresponding author. We thank Thomas Hemmer, Mark Lang, Ed Maydew, Doug Shackelford, Jake Thornock, Hal White and workshop participants at the University of North Carolina for comments. Any errors are our own. John Gallemore gratefully acknowledges the financial support of the Deloitte Foundation. Eva Labro gratefully acknowledges the financial support of the Kenan-Flagler Business School and the Latane fund. 


\title{
The Importance of the Internal Information Environment for Tax Avoidance
}

\begin{abstract}
We show that firms' ability to avoid taxes is greatly affected by the quality of the firm's internal information environment, with effective tax rates (ETRs) substantially lower for high internal information quality firms. Furthermore, we show that firms that experience an internal information quality improvement (reduction) are reducing (increasing) their ETRs. The effect of internal information quality on tax avoidance is strongest for firms in which information is likely to play a more important role. First, firms with high coordination needs because of their dispersed geographical or business industry presence benefit more from the reduced information asymmetry and improved information coordination between their various business units, allowing for more effective tax planning. Second, firms that are operating in a more uncertain environment are able to offset some of the negative effect of uncertainty on their ETRs through the quality of their internal information system. Because lower ETRs are obtained through better internal information quality, they do not come at the cost of increased risk in the tax positions taken: unrecognized tax benefits and ETR volatility are lower in high quality information environments.
\end{abstract}

Keywords: tax avoidance, internal information quality, management accounting

JEL Classification: M41

Data availability: Data are available from sources identified in the text. 


\section{INTRODUCTION}

We investigate the role the quality of the internal information environment plays in firms' ability to avoid taxes. Prior literature has studied firm-level characteristics such as firm size, profitability, leverage, capital intensity, foreign operations, and R\&D expenses (e.g. Cheng, Huang, Li, and Stanfield, 2012; Gupta and Newberry, 1997; Rego, 2003) that can help explain variation in the level of tax avoidance (Dyreng, Hanlon, and Maydew, 2008), but a significant proportion has remained unexplained. Increasingly, researchers have understood that we need to dig deeper inside the firm to obtain a better understanding of the tax planning processes and decisions that lead to the observable tax avoidance outcomes. For example, Shackelford and Shevlin (2001) call for developing bridges between tax and managerial accounting, arguing that tax, as an internal function of the organization, fits naturally with questions that interest managerial accounting researchers. More than a decade later, Hanlon (2012) suggests that more connections still need to be made between tax and management accounting.

In this paper, we will argue that in order to understand tax avoidance outcomes, it is necessary to consider the role the quality of the internal information environment of the firm plays in supporting tax planning decision making that can result in such outcomes. ${ }^{1}$ We define quality of the internal information environment (hereafter IIQ) in terms of the accessibility, usefulness, reliability, accuracy, quantity, and signal to noise ratio of the data and knowledge collected, generated, and consumed within an organization. High quality management accounting systems will allow a firm to obtain a high quality internal information environment. This aspect of the internal firm environment has so far mostly been ignored in the tax avoidance literature, yet seems crucial to the firm's ability to avoid taxes. ${ }^{2}$ Without good information, tax planning opportunities may not be visible, coordination of tax planning across business or

\footnotetext{
${ }^{1}$ Readers with a management accounting background will recognize "decision making" as one of the two pillars of management accounting practice, the other pillar being "performance management and control." Recent studies have looked at the interaction between tax avoidance and performance management and control, finding associations between measures of tax aggressiveness and the use of after-tax performance measures for business unit managers (Phillips, 2003), the value of stock option grants to the 5 highest paid executives (Desai and Dharmapala, 2006), the choice to evaluate corporate tax departments as profit centers as opposed to cost centers (Robinson, Sikes, and Weaver, 2010), tax director compensation (Armstrong, Blouin, and Larcker, 2012) and equity risk incentives (Rego and Wilson, 2012). The literature on the decision making aspect is much more limited, and Hanlon and Heitzman (2010) have called for more research on tax decision making within the firm, specifically regarding tax avoidance.

${ }^{2}$ A notable exception is Bauer (2011) who finds that firms with a tax-related internal control weakness have on average 4\% higher Cash ETRs. While Bauer (2011) focuses on how tax-related internal control weaknesses can provide relevant information to outside investors, we will argue that material weaknesses in internal control (irrespective of what they relate to) constitute (only) one specific aspect of the overall internal information environment that supports decision making by managers.
} 
geographic segments may be difficult or even impossible, risk taken in pursuing aggressive tax avoidance strategies may be very high and the firm's documentation may not constitute acceptable proof vis-à-vis the IRS. For example, Bayer predicts that it will take several years to sort through documentation problems related to sustain R\&D tax credits with the IRS dating back to 1998, since their accounting system cannot readily provide the required information (McKinnon, 2012). Furthermore, it is well known that globally coordinated transfer pricing schemes can allow multinational firms to avoid a substantial amount of taxes. However, Ernst \& Young's recent transfer pricing survey indicates that still only $41 \%$ of multinationals prepared transfer pricing documentation concurrently on a globally coordinated basis. The other 59 percent either prepared documentation for a single country (modifying to the needs of other jurisdictions as needed), prepared it on an as-necessary country-by-country basis with limited coordination between countries, or did not even prepare any transfer pricing documentation at all (Ernst and Young, 2010). ${ }^{3}$ The lack of information coordination in the majority of multinationals likely has a profound impact on their ability to avoid taxes.

In sum, understanding the quality of a firm's internal information environment is of major importance in explaining a firm's ability to avoid taxes and the risk the firm incurs when pursuing aggressive tax strategies. We will show the channels through which such IIQ has an effect on the efficacy of tax decision making, resulting in tax avoidance. In doing so, we explicate the importance of managerial accounting for tax accounting and respond to Maydew (2001)'s call to put information and uncertainty front and center when researching this particular taxation issue.

We use five publicly available proxies of the quality of firm's internal information environment: the speed by which management is able to bring out an earnings announcement after fiscal year closing, management forecast accuracy, the absence of material weaknesses in internal control, analyst following, and analyst forecast accuracy. While IIQ is by definition private to the firm and unobservable, we argue in Section 3 that these five measures capture this construct. We show that our results hold across the variety of these measures and with the

\footnotetext{
${ }^{3}$ Rossing and Rohde (2010) report on a case study where a large multinational firm thoroughly changed its managerial cost allocation system so that it could support the firm's transfer pricing compliance strategy.
} 
different cross-sectional predictions. We believe that the totality of our results validate our measures, and suggest that they can be used in further studies to serve as proxies for IIQ. ${ }^{4}$

Our findings demonstrate the important role IIQ plays in understanding tax planning decision making and its outcome, tax avoidance. We show that moving one quintile in our continuous measures is associated with a cash effective tax rate (Cash ETR) reduction of approximately 1 percent, and moving from the bottom quintile to the top quintile of our continuous measures is associated with reductions in Cash ETR ranging from 2.2 to 4.1 percent. Having a section 404 material weakness is associated with an increase in Cash ETR of 5.1 percent. This levels result extends to a change analysis, where we show that firms that experience a change in IIQ also change their degree of tax avoidance. ${ }^{5}$

Next, we investigate cross-sectional differences in the effect of IIQ on tax avoidance that help us understand through which mechanisms IIQ plays a role for achieving tax avoidance outcomes. First, we expect that IIQ is more important in firms with greater coordination needs because of their more dispersed geographical or business industry presence. Such firms benefit more from IIQ through reduced information asymmetry and improved information coordination between their various business units, allowing for more effective tax planning. We document that while both geographic and business industry segment dispersion indeed make tax avoidance more difficult, this effect is largely offset by improved IIQ. Second, we predict and find that operating in more uncertain environments (using the presence of restructuring charges and sales volatility as proxies for uncertainty) makes tax planning for firms more problematic. Tax opportunities may not be visible, there may be substantial doubts about the payoffs of particular tax planning opportunities, and forecasting over the wide range of potential tax outcomes may be difficult. We show that firms are able to offset some of the negative effects of such uncertainty on tax avoidance through the quality of their internal information system.

\footnotetext{
${ }^{4}$ As we will describe more fully later, management accounting researchers have typically needed to resort to creative use of (large scale) simulations or (small scale) proprietary data collection to overcome the unobservability issue. Our proxies allow for large scale, publicly observable, real life data, at the expense of weaker construct validity.

${ }^{5}$ Prior research has suggested that managers value both cash flows and book earnings when making tax planning decisions (Graham, Hanlon, and Shevlin, 2011; Shackelford, Slemrod, and Sallee, 2011). While our main analyses use the firm's cash effective tax rate as the empirical proxy for tax avoidance, we document that our findings are robust to employing the firm's book effective tax rate (GAAP ETR). Thus, our results indicate that having better IIQ allows the firm to engage in more tax avoidance for both cash flow and book purposes.
} 
Finally, we examine the effect of IIQ on tax risk. We define tax risk as the amount of uncertainty experienced by the corporate tax payer that is caused by the possibility of changes in its tax liability when its tax filings are not upheld by the tax authorities, and by the unpredictability thereof. ${ }^{6}$ Firms with greater tax risk are likely to reserve more for their tax positions ex ante, and experience more volatility in tax outcomes ex post. Thus, we use two measures of tax risk, one that captures budgeted tax risk at the time of the tax planning decisions, while the other indicates actual outcome tax risk. Reinforcing that the lower ETRs we document are obtained because of better IIQ that supports improved tax planning decision-making, we show that the increased tax avoidance outcome observed in high IIQ firms is not coming at the cost of higher tax risk. First, we use UTB as a measure of budgeted (planned) tax risk assumed at the time the tax positions are taken (Rego and Wilson, 2012). ${ }^{7}$ While higher IIQ reduces ETRs, we find that it is not positively associated with $U T B$, and with some of our proxies of IIQ we even document that higher IIQ is accompanied with significantly lower UTB. Second, we use cash ETR volatility over five years as a measure of tax outcome (ex post) risk (Guenther, Matsunaga, and Williams, 2012). ETR volatility is disliked by firms, tax consultants and tax directors alike (Ernst \& Young, 2011). We document that a high quality internal information environment helps achieve these objectives through reducing the riskiness of tax avoidance outcomes over time: ETR volatility is substantially lower in high quality information environments.

Hence, increased tax avoidance (as defined by Hanlon and Heitzman (2010) as the reduction of explicit taxes) can go hand in hand with decreased budgeted and outcome tax risk if the firm has high IIQ. This result sheds new light on the difficulty of conceptually defining tax avoidance or tax aggressiveness and the notion that such degree of aggressiveness is in the eye of the beholder (Hanlon and Heitzman, 2010). Referring to the model by Mills, Robinson, and Sansing (2010), both Frischmann, Shevlin, and Wilson (2008) and Rego and Wilson (2012) define aggressive tax reporting as engaging in significant tax positions with relatively weak supporting facts. Hence, in order to understand that what is aggressive for one firm may not be aggressive for another firm, we need to understand the quality of the internal information on which tax

\footnotetext{
${ }^{6}$ We do not study tax risk that results from the incompleteness of the tax law, and its many legislative, administrative, and judicial modifications (Blouin, Devereux, and Shackelford, 2012).

${ }^{7}$ Unrecognized tax benefits need to be reported for the largest amount of a tax benefit taken on the tax return that is more likely than not to be disallowed by the IRS.
} 
decisions are based. ${ }^{8}$ Our results suggest that when a firm has strong facts to support a tax planning strategy, they are not taking on more risk or behaving more aggressively when reducing ETR.

Of course, it is likely that there are certain characteristics of the firm that lead to both higher quality internal information and more tax avoidance opportunities. Furthermore, both IIQ and tax avoidance are choices of the firm, suggesting that endogeneity may be a concern. We conduct a battery of additional tests that we believe rule out correlated omitted variables and endogeneity as potential explanations for our results. In brief, we use an extensive set of carefully chosen control variables and industry fixed effects, we present consistent evidence with both a first difference and a lead-lag specification, and we report an analysis of the shock caused by the imposition of Sarbanes-Oxley on low IIQ firms. Furthermore, we show our results are robust to employing a long-run specification and additional control variables.

By examining the role of the firm's IIQ, our study helps to shed light on the black box of tax avoidance, which is of interest to academics, tax authorities, and practitioners. We document that IIQ is strongly related to the ability to engage in effective tax planning through (1) coordination via information dissemination, (2) resolution of uncertainty by means of information acquisition and (3) reduction of budgeted and actual tax risk. Furthermore, understanding the link between tax avoidance and the quality of the information on which tax planning decisions are based is essential to understanding what it means to be tax aggressive. For example, two firms with differing IIQ may be able to achieve the identical low effective tax rate. However, if the firm with high IIQ is better able to identify tax avoidance opportunities through increased information acquisition and dissemination and is more competent at carefully documenting its tax positions, whereas the low IIQ firm has to rely on tax shelters with little economic substance, then the firm with better IIQ has achieved its low tax rate with considerably less tax risk. This suggests that academics need to consider IIQ when studying tax aggressiveness. Furthermore, faced with the choice to allocate costly auditing resources to one of two firms with the same ETR, tax authorities are more likely to identify unsustainable tax positions in the firm with an internal information environment of low quality. ${ }^{9}$ Additionally, tax practitioners can emphasize the

\footnotetext{
${ }^{8}$ Note that neither Frischmann et al. (2008) nor Rego and Wilson (2012) control for the quality of information in their analyses.

${ }^{9}$ The tax authority is less likely to be able to overturn a tax position that was taken based on high IIQ. Moreover, Zhigang (2010) argues that the amount of visible audit cues is reduced when a firm has integrated their tax
} 
importance of management accounting systems that improve IIQ for effective tax avoidance. Finally, our findings demonstrate the importance of building bridges between managerial accounting and taxation research and practice.

The remainder of this paper is organized as follows. Section 2 reviews the related literature and develops the hypotheses. Section 3 elaborates on the IIQ proxies we use. In Section 4 we discuss research design, sample, and descriptive statistics. Section 5 presents the results of the study. Section 6 reports on endogeneity tests and robustness checks. Section 7 concludes and presents avenues for future research.

\section{HYPOTHESES DEVELOPMENT}

\subsection{Quality of the internal information environment}

The management accounting literature has long since argued that a high quality internal information environment will lead to improved managerial decision making (Horngren, Datar, Foster, Rajan, and Ittner, 2012). High quality management accounting systems such as enterprise systems can positively impact IIQ by providing management with real-time information concerning the financial condition of the company and eliminating barriers between accounting cycles (Brazel and Dang, 2008). This allows managers unprecedented access to accounting information. Information can be improved through centralized and standardized business transaction processing, reduction of reporting cycle times, and integration of data across business units and geographical locations. All of this will result in greater and timelier access to more accurate information and enhanced internal transparency. Both information acquisition (the task of finding information) and information integration (the task of assessing informational impact) will be improved (Hodge, Kennedy, and Mains, 2004). ${ }^{10}$

While improved managerial accounting systems are likely to have a positive impact on any managerial decision making, our focus here is on its effect of IIQ on enhancing the quality of tax planning decision making, with tax avoidance as a desirable outcome. We argue that a firm's ability to effectively plan taxes is improved by an internal information environment that makes

reporting in their overall ERP system, since there no longer is a paper trail for automated processes such as customer orders, purchase orders, and electronic payments.

${ }^{10} \mathrm{We}$ acknowledge that managerial ability in information processing and analyzing will also play a role in the quality of the decision making outcomes achieved. We look forward to future papers that open this part of the black box of tax decision making. An important step in this direction was taken by Dyreng, Hanlon, and Maydew (2010). 
both information acquisition and integration easier. ${ }^{11}$ Information necessary for the tax function is typically decentralized and buried within systems tailored for financial and management reporting (Cranford, Murias, and Schutzman, 2012). Documentation and collection of information from disparate systems to support tax compliance can be incredibly time consuming. Tax consultants are quoted to say that many firms pass on tax breaks that they are entitled to claim because the compliance and documentation costs are too high (as mentioned in the Bayer example above) (McKinnon, 2012). Similarly, Mills, Erickson, and Maydew (1998) argue that firms have tax planning opportunities around property, plant, and equipment, such as the decision of whether to buy or lease buildings and equipment and the timing of asset acquisitions and disposals, but that compliance and record keeping costs to achieve these opportunities are high (e.g. keeping track of depreciation method and cost for each fixed asset, and the use of different depreciation methods for regular and AMT tax). However, in a high internal information quality environment, tax compliance processes can be dealt with quickly and effectively, so that the tax department's resources can be freed up and allocated to pursuing tax planning opportunities. As a result, the firm will be able to avoid more taxes, which leads to our first hypothesis:

H1: As the quality of the internal information environment of the firm increases, tax avoidance increases.

\subsection{Coordination needs}

Decentralization usually means that there is more specific information available at a decentralized level (with business units and/or lower level managers), but that this information is not necessarily available to corporate management, and hence substantial information asymmetry may exists. While business units operating in different lines of business or geographic locations are less likely to interact (Bushman, Indjejikian, and Smith, 1995) and may hence have specific information available only to their own units, the tax function is an administrative function with responsibilities that permeate the entire firm. Regardless of how decentralized firms are, in most firms the tax department operates at the corporate level (Robinson et al., 2010). High dispersion

\footnotetext{
${ }^{11}$ In an interesting paper, Balakrishnan, Blouin, and Guay (2011) find that tax aggressiveness reduces firm transparency (that is, the quality of the external information environment), presumably due to the complexity of activities specifically designed to avoid taxes. Conversely, we look at how the quality of the internal information makes tax planning opportunities visible.
} 
of business units makes the coordination across those business units for tax planning difficult since each of those business units may prepare tax returns in several jurisdictions.

Existing survey evidence speaks to the perceived usefulness of improved information in the context of decentralization. Chenhall and Morris (1986) provide evidence that the usefulness of scope, aggregation, and integration of information is higher when there is decentralization and organizational interdependence. Chapman and Kihn (2009) show that managers' perceptions of enterprise systems success are a function of the extent of organizational integration created by the implementation of such systems, and that management's confidence in their internal information results from the improved integration of information across disparate business units. ${ }^{12}$ Viewing the tax department as a business unit that has specific private information, Robinson et al. (2010) discuss how organizing it as a profit center allows to solve the agency problem asymmetric information creates, by encouraging the department to consider overall firm performance. They find that tax departments that are organized as profit centers achieve lower book effective tax rates. An alternative way to overcome information asymmetry issues created by decentralization is to improve the internal information environment of the firm. This reduces information asymmetries between various business units, and between the corporate tax department and business units. Tax avoidance requires a lot of information and documentation coordination across business units to be effective, so we expect to see the largest effect of the quality of the internal information environment on tax avoidance in firms with high coordination needs.

High geographic and business industry dispersion also typifies firms with a lot of tax planning opportunities, yet also high compliance costs. Inter-jurisdictional income shifting for geographically dispersed firms can result in significant tax savings (Maydew, 2001), and Mills et al. (1998) document that such firms invest more in tax planning. Business industry dispersion may increase opportunities for tax avoidance through transfer pricing opportunities in the supply chain. However, documentation vis-à-vis tax authorities has to be maintained at all points in such a process. Improved coordination of information is likely to make such tax avoidance

\footnotetext{
${ }^{12}$ Note that existing evidence on the effects of improved information quality in management accounting (e.g. on adoption of Activity-Based Costing systems) typically looks at perceived outcomes. Few papers look at whether managers can actually make better decisions or if organizational performance is improved, as we do here (Ittner and Larcker, 2001).
} 
opportunities visible and reduce the cost of compliance. Both arguments lead us to our second hypothesis:

H2a: As a firm's coordination needs increase, tax avoidance decreases.

H2b: Higher internal information quality acts as an offset to the negative effect of a firm's coordination needs on tax avoidance.

\subsection{Uncertainty}

The basic effect of uncertainty is to limit the ability of managers of an organization to preplan or to make decisions about activities in advance of their execution. Uncertainty hence is likely to diminish a firm's tax planning ability, since tax opportunities may not be visible, there may be substantial doubts about the payoffs of particular tax avoidance opportunities, and forecasting over the wide range of potential tax outcomes may be difficult. Scotchmer and Slemrod (1989)'s model predicts that in an environment where there is a lot of uncertainty about the tax liability, firms will pay a higher amount of taxes to reduce the probability that a fine will be assessed. Consistent with the notion that uncertainty reduces tax avoidance, McGuire, Omer, and Wilde (2012) empirically find that firms working in an environment characterized by high operating uncertainty are less likely to engage in tax shelters.

Information economics has long since shown that uncertainty can be resolved by acquiring information. Early work by Galbraith (1974) indicates that with greater uncertainty, a greater amount of information must be processed among decision makers during task execution in order to achieve a given level of performance. One of the strategies Galbraith suggests to deal with uncertainty, so that firms can increase their ability to preplan, is increasing their capacity to process information by investing in information systems. Chenhall and Morris (1986) present survey evidence indicating that uncertainty makes planning more difficult and that the perceived usefulness of scope, timeliness, and various levels of aggregation of information is higher in uncertain environments.

While from an information economics perspective it is obvious that information plays a larger role in uncertain environments, surprisingly little tax accounting research has looked at uncertainty (and its resolution by information) as primary topics of interest (Maydew, $2001 \mathrm{pg}$. 
392). ${ }^{13}$ A notable exception is Beck, Davis, and Jung (1996) who, in an experiment, find that subjects that are exposed to more uncertainty about their tax liability are more likely to purchase advice of experts that possess information that can resolve this uncertainty. Information should be able to offset some of the negative effect of uncertainty on tax avoidance. This leads us to the following set of hypotheses:

H3a: As uncertainty increases, tax avoidance decreases.

H3b: Higher internal information quality acts as an offset to the negative effect of uncertainty on tax avoidance.

\subsection{Tax risk}

In their review paper, Hanlon and Heitzman (2010) discuss the difficulty of conceptually defining tax avoidance or tax aggressiveness and the notion that the degree of aggressiveness is in the eye of the beholder. ${ }^{14}$ We contend that it is crucial to import the notions of risk assumed by and information available to the firm during the tax planning decision in this discussion. To see this, imagine two firms (A and B) who both achieve a low ETR of 15 percent (the tax outcome variable). Firm A can achieve such low ETR by relying on high quality information to support its decision making and its documentation vis-à-vis the taxation authorities, and assumes very little risk in the tax positions it takes. Firm B is only able to achieve this low ETR by pursuing very risky tax avoidance opportunities since it does not have access to good information and has little ability to convincingly document these strategies. The likelihood that Firm B's tax avoidance choices will be disallowed by the taxation authorities is high. Thus, Firm B's tax risk is high. Hence, we would argue that Firm B is much more tax aggressive than Firm A.

Some empirical papers have incorporated this notion that the quality of information is important in defining tax aggressiveness. Referring back to the model by Mills et al. (2010), both Frischmann et al. (2008) and Rego and Wilson (2012) define aggressive (or risky) tax reporting as engaging in significant tax positions with relatively weak supporting facts. ${ }^{15} \mathrm{We}$ follow Rego

\footnotetext{
${ }^{13}$ Note that the economics literature has studied uncertainty around taxation, but their focus is typically not on the role of information provision to resolve uncertainty within firms. Rather, they discuss the uncertainty created by governmental changes in tax policy.

${ }^{14}$ Also practitioners have called for the need to agree on an acceptable definition of what constitutes aggressive tax planning in order to adopt "enlightened" tax risk management programs (Klotsche and Traubenberg, 2010).

${ }^{15}$ One of the predictions in Mills et al. (2010) is that those firms with "strong facts" are better off post FIN48 as they now can use this mandatory disclosure mechanism to credibly communicate that they have low uncertainty on their tax positions, and achieve a higher expected payoff as a result. However, note that they do not model a cross-
} 
and Wilson (2012) who argue that unrecognized tax benefits (UTB) are the best proxy for the concept of "risky tax avoidance." UTB need to be reported for the largest amount of tax benefit taken on the tax return that is judged more likely than not to not be upheld by the IRS. Hence, we use $U T B$ as a measure of budgeted (planned) tax risk assumed at the time the tax positions are taken.

Firms with a higher quality internal information environment have better information to support their tax planning decision making, higher confidence in their information endowment (Chenhall, 2008) and better documentation ability vis-à-vis taxation authorities. All of these affect both the level of tax avoidance and the risk assumed in pursuing those tax avoidance opportunities. Since we argued in hypothesis 1 that higher quality information will increase tax avoidance opportunities, there are three scenarios that could possibly materialize: (1) firms increased tax avoidance while assuming less risk, (2) firms kept their risk profile the same, or (3) firms increased the risk assumed. Since high IIQ allows for better documentation with regards to the taxing authority, it reduces the risk that any given tax position will be overturned upon audit. Furthermore, we have no reason to think that high IIQ firms would typically be more risk seeking than other firms; in fact, the opposite is likely to be the case. Hence, such firms may well be in a position to make effective tax planning decisions (as hypothesized in H1) without needing to assume high levels of risk. ${ }^{16}$ This leads us to our fourth hypothesis:

H4: As the quality of the internal information environment of the firm increases, budgeted tax risk assumed decreases.

While we have argued that $U T B$ is a measure of the riskiness assumed at the time of making a tax planning decision (or the budgeted amount of risk), another important aspect of the riskiness of the tax position lies in the tax outcome risk (the actual amount of risk). We use 5year ETR volatility as a measure of such tax outcome risk (Guenther et al., 2012; McGuire, Neuman, and Omer, 2011). Firms dislike ETR volatility, and typically feel the need to explain

sectional variation on the quality of information available to firms (all firms are modeled to have perfect internal information). The cross-sectional variation on the "strong facts" parameter refers to the level of the expected tax benefits being high versus low.

${ }^{16}$ As discussed by Hanlon and Heitzman (2010), UTB is a self-reported measure around which the firm can have strategic reporting incentives, which may make its interpretation not as clear-cut. Underreporting of UTB, which there may well be for strategic reasons that involve keeping the asymmetry of information between the IRS and the firm as high as possible, decreases our measure of risk. However, we cannot think of a reason why those with better information would underreport more than those with worse information, so potential underreporting should not bias in favor of our result. 
high ETR volatility extensively in their communications with investors. ${ }^{17}$ A recent Ernst \& Young whitepaper states " $[\mathrm{t}]$ he market expects improved management of tax risks, together with increased controls and faster reporting times with no surprises" (Ernst \& Young, 2011). CFOs say that fluctuations in ETR drive down firms' earnings quality (Dichev, Graham, Harvey, and Rajgopal, 2012). Tax consultants discuss ETR volatility as an important statistic to be used in benchmarking (PriceWaterhouseCoopers, 2012). Tax directors want to be able to stand in front of their board with the confidence that tax is under control and that there is no risk of meaningful surprises (Viglione and Norton, 2009). They dislike any unpredictability caused by potentially overturned positions. Just as the amount of risk assumed at the time of making the tax planning decision is likely to be lower in a high quality information environment, the amount of risk actually incurred should also be lower. Furthermore, better internal information allows the firm to find more long term tax avoidance opportunities with recurring benefits rather than necessitating it to run after one-time opportunities (Mills et al., 1998), resulting in low variation of ETR over the years. ${ }^{18}$ Both reasons lead us to our fifth hypothesis:

H5: As the quality of the internal information environment of the firm increases, actual outcome tax risk decreases.

\section{INTERNAL INFORMATION QUALITY PROXIES}

Managerial accounting research has often struggled with the unavailability of a good proxy for the quality of the internal information environment. As mentioned earlier, a firm's internal information is by definition private to the firm and in particular the quality of management accounting systems is typically not publically observable. Also, while theoretical models often assume that perfect information is available to the firm, such benchmark against which to assess the quality of any given information system is empirically not obtainable. Hence, an absolute

\footnotetext{
${ }^{17}$ For example, Synaptics wrote in their 2012 10-K: "The calculation of tax liabilities involves significant judgment in estimating the impact of uncertainties in the application of highly complex tax laws. Resolution of these uncertainties in a manner inconsistent with our expectations could have a material impact on our consolidated financial position, result of operations, or cash flows. We believe we have adequately provided for reasonably foreseeable outcomes in connection with the resolution of income tax uncertainties. However, our results have in the past, and could in the future, include favorable and unfavorable adjustments to our estimated tax liabilities in the period a determination of such estimated tax liability is made or resolved, upon the filing of an amended return, upon a change in facts, circumstances, or interpretation, or upon the expiration of a statute of limitation. Accordingly, our effective tax rate could fluctuate materially from period to period. [...] As a result, our future quarterly and annual effective tax rates will be subject to greater volatility."

${ }^{18}$ Note that we look at the second moment of ETR over 5 years, which is different from Dyreng et al. (2008) who look at average ETR over a longer period (the first moment).
} 
measure of IIQ is impossible to calculate. Out of necessity, management accounting researchers have resorted to survey methods to measure the (perceived) quality of management accounting systems (e.g. Chenhall and Morris, 1986; Ittner, Lanen, and Larcker, 2002; Maiga and Jacobs, 2008) or used simulation methods that make such perfect information benchmark observable (e.g. Balakrishnan, Hansen, and Labro, 2011; Labro and Vanhoucke, 2007). Only few papers have used publically available data to proxy for the quality of the internal information environment. Notable exceptions are Feng, Li, and McVay (2009) who use disclosures on material weaknesses in internal control as a proxy for low quality of the internal information environment and Jennings, Stoumbos, and Tanlu (2012) who use the number of days between the end of the quarter and the earnings announcements, whereby a shorter time span proxies for the existence of better quality internal information.

In this study we employ five proxies for the quality of the internal information environment of the firm that are all publically observable and available in large datasets (at least in comparison to the size of datasets with which managerial accounting researchers typically work). ${ }^{19}$ Working with publicly available proxies allows us to examine the effect of IIQ on tax avoidance in a large sample and over a long period. Our five proxies are the time lag between the end of the fiscal year and the earnings announcement date, management forecast accuracy, material weaknesses in controls, and two characteristics of the analyst information environment (analyst following and analyst forecast accuracy). We discuss each proxy below.

First, we follow Jennings et al. (2012) who capture the sophistication of internal accounting systems by counting the number of days between the end of the quarter and the earnings announcement date. ${ }^{20}$ They argue that a high quality accounting system that is capable of integrating information from different parts of an organization allows for the books to be closed more quickly than its low IIQ counterpart, where information from the various subsidiaries needs to be manually combined in ad hoc spreadsheets. Hence, a shorter time lag between the quarterend and earnings announcement can be achieved in a high IIQ environment. Additionally to this information coordination aspect which Jennings et al. (2012) explain, increased accuracy caused by eliminating manual intervention, reducing redundancy and rework, and streamlined reporting

\footnotetext{
${ }^{19}$ While the advantage of using publicly available proxies is that sample size and generalizability are increased and data availability is not a concern, moving away from privately collected (e.g. through surveys or case studies) data to define proxies comes with the drawback of capturing the construct of internal information quality with less precision.

${ }^{20}$ We use end of the fiscal year instead of end of the quarter since we employ annual tax data.
} 
should also reduce such time lag. Further, firms that have an automated financial closing process in place have typically received help from professionals in installing this, and will have been advised on how to improve their information acquisition processes. In a series of interviews, CFOs from companies around the globe commented on how a quick financial close meant that their firms also had the ability to deliver management information more quickly and more accurately (CFOResearchServices, 2010). Related, Brazel and Dang (2008) find that after firms implement ERP systems, they experience a reduction in the time difference between the firms' earnings announcement dates and their fiscal year end.

Second, we include management forecast accuracy. It has long since been established that management has incentives to forecast accurately (Williams, 1996). However, in order to be able to provide an accurate management forecast, managers must have access to good quality internal information (Jennings et al., 2012). Using hand collected data from news releases of firms that implemented improvements to their information systems, Dorantes, Li, Peters, and Richardson (2012, forthcoming) show that these firms increased management forecast accuracy after such implementation. They provide corroborating evidence that such improvement is caused by an improvement of the quality of the internal information system, and not by the enhanced ability of managers to manage earnings. ${ }^{21}$ Using survey data of small privately held firms, Cassar and Gibson (2008) establish that if such firms have internal accounting reporting and budgeting processes in place, they make more accurate revenue forecasts. It follows that empirical evidence indicates that the quality of the internal information environment must be positively correlated with management forecast accuracy. ${ }^{22}$ Also, we are not aware of any research that suggests any (possibly strategic) reasons why the correlation would be negative. Indeed, ceteris paribus, it is hard to imagine any strategic reasons for a firm with high IIQ to deliberately disclose a very

\footnotetext{
${ }^{21}$ Related, Gong, Li, and Xie (2009) document that common errors in management forecasts and accruals are caused by errors in the private information available to the managers in the firm.

${ }^{22}$ Predictions from theoretical models indicate a positive correlation between the precision of private information and the likelihood of disclosure. In a setting where the markets knows that the manager of the firm is endowed with private information but where there is a proprietary cost to disclosing this information, Verrecchia (1990) predicts that as the private information of the manager becomes more precise, the threshold level of disclosure decreases and the probability of disclosure increases. To our knowledge, there are no theoretical models that link the precision of private information to the precision of the disclosure (management forecast). For example, information endowment models such as Jung and Kwon (1988) typically assume there is either no private information (infinite imprecision) or perfect private information, and the disclosure decision is a binary one (yes or no disclosure). Further, Verrecchia (1990) argues that it is not clear that binary information endowment models can be interpreted as providing a measure of the quality of the information environment. In their review paper Beyer, Cohen, Lys, and Walther (2010) state that the process by which managers receive information has not been studied in the disclosure literature (pg. $305)$.
} 
inaccurate earnings forecast or, conversely, a firm with poor IIQ having the ability to make a very accurate earnings forecast. ${ }^{23}$

Third, following Feng et al. (2009), we use the presence of a material weakness in internal controls reported under Section 404 as a proxy for the lack of IIQ. They argue that some material weaknesses are likely to result in erroneous internal management reports that are unlikely to be detected since they are not audited. Also, these material weaknesses are likely resulting in untimely and stale financial reporting information. Furthermore, business unit information may not be timely and accurately reported to headquarters. ${ }^{24}$ Consistent with the assumed correlation with our second proxy, Feng et al. (2009) and Li, Peters, Richardson, and Weidenmier (2012) find that firms with material weaknesses in internal controls provide less accurate management forecasts. Using hand collected data from Lexis-Nexis news releases of firms that implemented (specific) internal control monitoring information technology, Masli, Peters, Richardson, and Sanchez (2010) show that after such implementation the likelihood of a material weakness decreases. Their results are stronger for firms that embed such improved information technology within the larger enterprise wide information environment (the more general internal information environment). Also, Morris (2011) shows that firms implementing ERP systems (which improves the quality of the information within the firm) are less likely to report a material weakness. Finally, material weakness disclosures typically trigger big investments in accounting systems, supporting in particular our changes analyses where after the resolution of a material weakness the firm's environment will be improved (Chasan, 2012).

Lastly, we use IIQ proxies based on the analysts' information environment: analyst following and analyst forecast accuracy. More analyst following and better analyst forecast accuracy generally are indicative of a better external information environment, whereas the delay between the end of the quarter and the earnings announcement, the accuracy of management

\footnotetext{
${ }^{23} \mathrm{We}$ are only able to observe the accuracy of the management forecast for those firms that issue guidance. If managers issue guidance only if the quality of their disclosure is sufficiently high, this should reduce variation in our management forecast accuracy measure, thereby reducing the power of our tests.

${ }^{24}$ For example, Corporate Resource Services reports in its 2010 10-K filing that a "material weakness resulted from a lack of sufficient and effective supervisory review over the preparation and reconciliation of certain general ledger account balances to their underlying source documents at one of our subsidiaries" and that as part of the remediation of this weakness they will "develop or address, depending on the circumstances, detailed financial reporting procedures to ensure that each subsidiary provides timely, complete and accurate information to the Company's headquarters for the preparation of financial reports which include all necessary disclosures." For further examples on how material weaknesses impact the quality of the firm's internal information environment, please refer to Feng et al. (2009).
} 
forecasts, and the existence of a material weakness in internal control are much more clearly linked to the quality of the internal information environment, which we are trying to capture. However, we argue that the internal and external information environments of the firm are intricately and tightly linked (Dichev et al., 2012; Hemmer and Labro, 2008). Prior literature suggests that there may be a positive correlation between our analyst variables and the quality of the internal information environment. Much of the information analysts use is directly provided by the firm (Lang and Lundholm, 1996), hence the quality of the internal information environment should be positively correlated with the quality of the analysts' information environment. Indeed, Lang and Lundholm (1996) show that analysts prefer to follow firms with an enhanced information environment and analyst forecast error is smaller for these firms. Stoumbos and Tanlu (2009) conjecture that a larger analyst following signals a greater likelihood that managers are endowed with information and that the quantity of information production by managers is larger. If analysts are able to obtain enough information about a firm to prepare analyst reports and make recommendations, then it is likely that managers have access to more and better information about the firms they manage, especially in the time period after Regulation Fair Disclosure where the internal and external information environments are more alike. Indeed, the analyst's decision to initiate coverage is linked to his ability to generate precise information (Beyer et al., 2010). Consistent with the notion that higher quality internal information is a prerequisite to higher quality of analyst information, research has shown that as the number of conference calls increases analyst forecast error decreases (Bowen, Davis, and Matsumoto, 2002), and that analyst following increases after company presentations (Francis, Hanna, and Philbrick, 1997). Dorantes et al. (2012, forthcoming) find that firms that are implementing ERP systems (arguably an improvement to their internal information environment) have a larger analyst following.

Thus, extant literature suggests a positive correlation between our analyst variables and the quality of the internal information environment. Furthermore, to our knowledge, no research points to the opposite, and argues a negative correlation. ${ }^{25}$ While the analyst literature has established that analysts may not always embrace accuracy in their forecasts as their overruling

\footnotetext{
${ }^{25}$ The feedback effect literature (e.g. Luo (2005)) suggests that the insiders to the firm sometimes learn from information produced by outsiders (e.g. analysts). While the temporal assumption in this literature may be different from what we described above, also this literature still implies a positive correlation between the qualities of the analysts' and internal information environments.
} 
objective and documents specific biases, there is no (strategic) reason to expect that such inaccuracy would be larger for firms with high quality internal information and/or smaller for firms with low quality internal information. Further, in line with existing literature, the correlation patterns between all proxies for the quality of the internal information environment reported in table 1 indicates that they are all positively correlated, with the highest correlations between analyst forecast accuracy and analyst following on the one hand, and management forecast accuracy and speediness of the earnings announcement on the other hand. ${ }^{26}$ The advantage of including the analyst variables as part of our larger set of proxies is that they are available for a much larger sample than management forecasts and material weaknesses, helping us overcome the stumbling block of finding large scale publically available proxies for IIQ.

\section{RESEARCH DESIGN, SAMPLE, AND DESCRIPTIVE STATISTICS}

\subsection{Research Design}

We employ the following regression specification to test our hypotheses:

Tax Avoidance Proxy Prt

$$
\begin{aligned}
& =\alpha_{0}+\alpha_{1} \text { Info Quality }_{i, t}+\sum_{k} \alpha_{k} \text { Controls }_{i, k, t} \\
& +\sum_{j} \alpha_{j} \text { Industry Fixed Effects }_{i}+\sum_{l} \alpha_{l} \text { Year Fixed Effects }_{t}+\varepsilon_{i, t}
\end{aligned}
$$

In testing hypotheses 1, 2, and 3, we use the firm's annual cash effective tax rate (Cash ETR) as our tax avoidance proxy, where Cash ETR is defined as the firm's cash taxes paid divided by the adjusted pre-tax income (pre-tax income minus special items). For hypothesis 4, we employ the firm's unrecognized tax benefit $(U T B)$, which is measured as the average $U T B$ over the year scaled by average total assets. Finally, to test hypothesis 5 we use as the tax avoidance proxy the 5-year volatility of the annual cash effective tax rate (Cash ETR Volatility), which is the standard deviation of Cash ETR over the current 5-year period.

We use Cash ETR as our primary measure of tax avoidance in order to avoid any mechanical relations between our tax avoidance proxy and our IIQ proxies, some of which are associated with accounting earnings (such as management forecast accuracy and analyst forecast

\footnotetext{
${ }^{26}$ For example, positive correlations have been documented between analyst forecast accuracy and analyst following (Lang and Lundholm, 1996), absence of material weaknesses and management forecast accuracy (Feng et al., 2009; Li et al., 2012), management forecast accuracy and analyst following (Baginski and Hassell, 1997) and management forecast accuracy and analyst forecast accuracy (Coller and Yohn, 1998; Schreuder and Klaassen, 1984).
} 
accuracy). Prior research has shown that managers use tax expense and the valuation allowance to manage earnings (Dhaliwal, Gleason, and Mills, 2004; Frank and Rego, 2006; Schrand and Wong, 2003). Cash effective tax rates do not use tax expense in the numerator and are unaffected by changes in the valuation allowance or tax cushion (Dyreng et al., 2008). However, in robustness checks, we show our inferences do not change when we use tax avoidance proxies that have an accrual component (GAAP ETR and book-tax difference). Hence, we argue that the firm's IIQ affects tax avoidance for both cash and book purposes.

As discussed above, we employ five different proxies for internal information quality: the number of days between the end of the fiscal year and the earnings announcement multiplied by 1 (EA Speed), the difference between the management earnings forecast and the actual earnings divided by price and multiplied by $-1(M F A c c)$, an indicator variable equal to one if the firm did not report a section 404 material weakness and zero otherwise (No $M W$ ), the log of the number of analyst forecasts (Analyst Following), and the difference between the median analyst forecast and the actual earnings divided by price multiplied by -1 ( $A F A c c)$. Note that, for all of these variables, higher values indicate better IIQ. MF Acc, Analyst Following, and AF Acc are measured using the last available observation before the fiscal period end. In the regressions, each of the continuous information proxies (EA Speed, MF Acc, Analyst Following, and AF Acc) are ranked into quintiles in each year and scaled such that they range from 0 (the lowest quintile) to 1 (the highest quintile). Thus, the coefficients on these IIQ proxies can be interpreted as the effect of moving from the bottom quintile to the top quintile on the tax avoidance proxy, whereas the coefficient on $N o M W$ can be interpreted as the effect of not having a section 404 material weakness. We expect a negative coefficient on each IIQ proxy, consistent with better information allowing for more tax avoidance.

We include a number of control variables that prior research has shown to be associated with tax avoidance outcomes (Cheng et al., 2012; Dyreng et al., 2008; McGuire et al., 2012; Phillips, 2003; Rego, 2003; Rego and Wilson, 2012). Size is the natural logarithm of average total assets, and prior research has found significant yet mixed signed results. $P P E$ and $\triangle P P E$ are the average property, plant, and equipment scaled by average total assets and the change in property, plant, and equipment scaled by average total assets, respectively. ${ }^{27} \mathrm{We}$ capture the

\footnotetext{
27 As in Dyreng et al. (2008), we expect capital intensive firms to have more tax planning opportunities, and the change in PPE to be associated with benefits of accelerated depreciation for tax purposes.
} 
firm's interest tax shield by including Leverage, which is the firm's average long-term debt scaled by average total assets. Intangibles, measured as the average intangible assets scaled by average total assets, are a proxy for the firm's ability to shift income. Since firms receive tax credits for research and development, we include $R \& D$ Expense, which is the firm's $\mathrm{R} \& \mathrm{D}$ expense divided by average total assets. We include two proxies that capture the extent to which firms may have prior operating losses, NOL Dummy and $\triangle N O L$, which are an indicator variable capturing whether the firm has a net operating loss carryforward at the beginning of the year and the change in the net operating loss carryforward scaled by average total assets, respectively. Both will result in the firm paying less tax. Extraordinary is the firm's extraordinary items scaled by average total assets. ${ }^{28}$ We use two measures of the extent of the firm's foreign operations that have been found in prior research to explain tax avoidance, albeit with inconsistent signs: Foreign Income, which is the firm's foreign income scaled by average total assets, and FI Dummy, which is an indicator variable equal to one if foreign income is non-zero and zero otherwise. Incentives to do tax avoidance are likely to vary with profitability, so we include $R O A$, the firm's operating income before depreciation scaled by average total assets. We include the market-to-book ratio $(M T B)$, measured as average market equity scaled by average book equity. As a proxy for growth we employ Sales Growth, measured as the change in sales scaled by average total assets. We include the firm's age (Age), which is the log of the number of years since the first year the firm was on Compustat, since younger firms may have differential incentives and ability to avoid taxes than older firms. Finally, we include industry and firm year fixed effects in order to capture differences in tax avoidance across industries and time. ${ }^{29}$ All variables are defined in the appendix.

To the extent that uncertainty drives both poor IIQ and makes tax planning more difficult, it could represent a correlated omitted variable in our analysis. Indeed, we hypothesize (H3) and find that uncertainty makes tax planning more complicated. Also, at least for some of our IIQ proxies, prior literature has established that they may be correlated with uncertainty. ${ }^{30}$ We include an additional control variable, Sales Volatility, to capture the general uncertainty

\footnotetext{
${ }^{28}$ Extraordinary items are not reflected in the denominator of the ETR, since they are reported below pretax income. However, it is likely that firms pay at least some cash tax on income from extraordinary items, which will be reflected in the cash tax paid numerator, and hence we predict a positive coefficient.

${ }^{29}$ Inclusion of industry fixed effects also mitigates endogeneity concerns resulting from industries likely having differing quality of internal information as well as tax avoidance opportunities and abilities.

${ }^{30}$ For example, Feng and Koch (2010) report on a positive correlation between uncertainty and management forecast error.
} 
regarding the firm's operating environment. ${ }^{31}$ We predict a negative coefficient on Sales Volatility. $^{32}$

In testing hypothesis 5, we use the specification in equation 1 , but modify the measurements of each variable to match the 5-year period over which we calculate Cash ETR Volatility. For our information proxies, we calculate the average of the ranked variable over the 5-year period. We also measure our control variables over the 5-year period. We still include industry and year fixed effects in this analysis.

To test hypotheses 2 and 3, we add an interaction term to equation 1 as follows:

Tax Avoidance Proxy Prt

$$
\begin{aligned}
& =\alpha_{0}+\alpha_{1} \text { Info Quality }_{i, t}+\alpha_{2} \text { Coordination Need }_{i, t} \\
& +\alpha_{3} \text { Info Quality } * \text { Coordination Needs }_{i, t}+\sum_{k} \alpha_{k} \text { Controls }_{i, k, t} \\
& +\sum_{j} \alpha_{j} \text { Industry Fixed Effects }{ }_{i}+\sum_{l} \alpha_{l} \text { Year Fixed Effects }{ }_{t}+\varepsilon_{i, t}
\end{aligned}
$$

$$
\begin{aligned}
& \text { Tax Avoidance } \text { Proxy }_{i, t} \\
& \qquad \alpha_{0}+\alpha_{1} \text { Info Quality }_{i, t}+\alpha_{2} \text { Uncertainty }_{i, t} \\
& +\alpha_{3}{\text { Info Quality } * \text { Uncertainty }_{i, t}+\sum_{k} \alpha_{k} \text { Controls }_{i, k, t}}+\sum_{j} \alpha_{j} \text { Industry Fixed Effects }_{i}+\sum_{l} \alpha_{l} \text { Year Fixed Effects }_{t}+\varepsilon_{i, t}
\end{aligned}
$$

For equations 2 and 3 we use Cash ETR as the tax avoidance proxy. We include the same set of control variables as in equation 1, as well as industry and year fixed effects.

In equation 2 we use two different measures of coordination needs. Bushman et al. (2004) measure segment concentration as the sum of the squares of firm sales in each segment scaled by total firm sales. Using this measure, a firm with ten segments with equal sales would have a segment concentration of 0.10 , whereas a firm with only one segment would have a segment concentration of 1 . In a similar spirit, we create a proxy for segment dispersion, which is measured as the segment concentration minus 1 then multiplied by -1 . Continuing the above example, the firm with ten segments with equal sales would have a segment dispersion value of 0.9 while the firm with only one segment would have a segment dispersion value of zero. We use

\footnotetext{
${ }^{31}$ Furthermore, we conduct two cross-sectional tests in the next section, and a change analysis in the sixth section to reduce concerns of correlated omitted variables.

${ }^{32}$ We use the standard deviation of sales rather than that of other variables (such as net income) because the former is less affected by managerial actions such as earnings management.
} 
two versions of our segment dispersion measure to capture coordination needs: Geographic Dispersion and Business Dispersion, which use geographic and business segments, respectively. We expect both coordination needs proxies to be positively associated with Cash ETR, as firm coordination difficulties inhibits effective tax planning. Furthermore, we expect a negative coefficient on the interaction of Info Quality and Organizational Complexity, consistent with the negative effect of firm coordination needs on tax avoidance being reduced for firms with higher quality information.

In equation 3 we employ two measures of uncertainty. Restructure is an indicator variable equal to 1 if the firm reports a restructuring expense and zero otherwise. Sales Volatility is the standard deviation of the firm's sales over the current five year period, scaled by the median assets over the period. Restructure captures whether the firm is undergoing a time of increased uncertainty, and Sales Volatility, as discussed above, captures the uncertainty of the firm's operating environment. We expect that the coefficients on Restructure and Sales Volatility will be positive, consistent with times of increased uncertainty and volatile operating environments making it more difficult to achieve favorable tax avoidance outcomes. However, consistent with hypothesis 3, we expect a negative coefficient on the interaction of our IIQ proxy and our uncertainty proxies, consistent with better IIQ helping alleviate the negative effect of uncertainty on tax avoidance.

\subsection{Sample and Descriptive Statistics}

We employ financial accounting and segment data from Compustat, stock market data from CRSP, earnings announcement as well as management and analyst forecast data from IBES, and section 404 material weakness data from Audit Analytics. ${ }^{33}$ We follow Dyreng and Lindsey (2009, pg. 1296) and set the following variables to zero if missing in Compustat: advertising expense, research and development expense, tax loss carryforwards, intangible assets, special items, and long-term debt. Furthermore, we employ their methodology to correct for errors in foreign tax expense, foreign pre-tax income, pre-tax domestic income, total pre-tax income, federal current tax expense, and worldwide current tax expense.

\footnotetext{
${ }^{33}$ In the 404 dataset, the auditor will provide an adverse opinion when the internal control system is found to be ineffective due to a material weakness, which we use to construct our indicator variable. There is a very high correlation between the instance of a 404 material weakness 404 and a 302 material weakness over our sample period (2004-2010), and results based on No $302 M W$ are very similar.
} 
Our sample period runs from 1994 to 2010. We begin our sample period in 1994, post the enactment of SFAS No. 109, to have consistent accounting for income taxes throughout the sample. For a firm-year observation to make our sample, it has to have non-missing data for each control variable and at least one IIQ proxy. Four of our IIQ proxies (EA Speed, MF Acc, Analyst Following, and AF Acc) are available throughout the entire time period (1994 to 2010), whereas No $M W$ is only available from 2004 to 2010. The number of firm-years in our annual Cash ETR regressions range from 8,963 (using $M F A c c$ ) to 32,591 (using EA Speed). The sample size is reduced when we investigate UTB (which is only available from 2007 to 2010) and Cash ETR Volatility (which uses variables measured over five year periods).

Panel A of Table 1 contains descriptive statistics for our sample. ${ }^{34}$ For the purposes of Table 1, we tabulate the unranked versions of our IIQ proxies. The average Cash ETR is 26\% and the 5-year standard deviation is $12 \%$. Panel B contains correlations for our sample variables. For brevity, we only tabulate the correlations for the tax avoidance proxies, the IIQ proxies, and the coordination needs and uncertainty variables. Cash ETR and Cash ETR Volatility are generally negatively correlated with our IIQ proxies, consistent with better IIQ allowing for more effective tax avoidance. However, the correlations between UTB and the IIQ proxies are inconsistent (three of five Pearson correlations are negative). Turning to the IIQ proxies, all proxies are positively correlated, with Pearson correlations ranging from 0.07 to $0.44 .{ }^{35}$ This provides reassurance that all our measures capture the same underlying concept of the quality of the firm's internal information environment.

[Insert Table 1 here.]

\section{RESULTS}

\subsection{Internal Information Quality and Tax Avoidance}

First, we examine whether firms that have better IIQ are able to achieve more favorable tax avoidance outcomes (hypothesis 1). To test this, we estimate equation 1 via OLS with Cash ETR as the dependent variable. Table 2 contains the results of this analysis. Each column employs a different IIQ proxy (from left to right: EA Speed, MF Acc, No MW, Analyst Following, and $A F A c c$ ), and contains the full set of control variables as well as industry and year

\footnotetext{
${ }^{34}$ Variables are based on amounts denominated in millions of U.S. dollars. All continuous variables are winsorized at 1 percent and 99 percent, except for Cash ETR which is winsorized at 0 and 1.

${ }^{35}$ Correlations between the ranked IIQ proxies are qualitatively similar.
} 
fixed effects (coefficients on fixed effects not reported). In general, the coefficients on the control variables are statistically significant and match those found in prior research. For example, the coefficients on PPE, $\triangle P P E$, Leverage, R\&D Expense, NOL Dummy, and Foreign Income are all negative, consistent with depreciation, interest expense, research and development, prior losses, and foreign income decreasing Cash ETRs. Extraordinary items increase Cash ETR, as predicted.

Using each of the five proxies, we find a negative relation between IIQ and Cash ETR. The relation is statistically significant, with all five $\mathrm{p}$-values less than $0.01{ }^{36}$ The coefficients on the IIQ proxies indicate that moving one quintile in the ranked variables is associated with a decrease in Cash ETR of approximately 1 percent, and moving from the bottom quintile to the top quintile in the ranked variables is associated with decreases in Cash ETR ranging from 2.2 percent to 4.1 percent. Having a section 404 material weakness is associated with an increase in Cash ETR of 5.1 percent. This is in line with Bauer (2011) and consistent with a section 404 material weakness being indicative of being a firm at the very extreme low end of the IIQ spectrum. ${ }^{37}$ Overall, these results indicate that firms with better quality information have lower Cash ETR, consistent with these firms being better able to engage in effective tax avoidance.

[Insert Table 2 here.]

\subsection{Internal Information Quality, Coordination, and Tax Avoidance}

Next, we test whether more disparate organizations that have greater coordination needs have less favorable tax avoidance outcomes, and whether IIQ helps such firms coordinate in order to achieve more effective tax avoidance outcomes (hypotheses $2 \mathrm{a}$ and $2 \mathrm{~b}$ ). Table 3 contains the results of estimating equation 2 via OLS with Cash ETR as the proxy for tax avoidance. As in Table 2, each column employs a different proxy for IIQ. For brevity, we only report the

\footnotetext{
${ }^{36}$ Statistical inferences are made using one-tailed tests for variables with predictions, and two-tailed tests otherwise.

${ }^{37}$ Note that Bauer (2011) finds significant results on tax-related material weaknesses only: In his 2004 to 2006 sample, he finds that firms with a tax-related material weakness on average have a $4 \%$ higher Cash ETR. Our finding of a higher increase of 5\% as a consequence of any internal control material weakness suggests that our variable No $M W$ indeed proxies for the entire internal information environment of the firm, and not solely for the quality of strictly tax-related information. The comparison of these results suggests that the quality of the internal information environment as a whole is important to pursue effective tax planning.
} 
coefficients on the IIQ proxy, the dispersion proxy, and the interaction term. Panel A examines geographic segment dispersion and panel B investigates business segment dispersion. ${ }^{38}$

In panel A, Geographic Dispersion is positive and statistically significant in all five regressions, consistent with geographic segment dispersion inhibiting effective tax avoidance. The magnitudes of the coefficients indicate that a one standard deviation increase in Geographic Dispersion is associated with a 3 to 4 percent increase in Cash ETR. However, the negative effect of geographic dispersion on tax avoidance is mitigated for firms with better IIQ: the coefficient on the interaction of IIQ and Geographic Dispersion is negative and highly significant using all five IIQ proxies. The amount of mitigation ranges from approximately 50 percent for firms without a $404 \mathrm{MW}$ to approximately 90 percent for firms in the top quintile of $A F$ Acc. These results are broadly consistent with IIQ alleviating the negative effects of geographic dispersion on tax avoidance.

We also investigate the effect of business unit dispersion (panel B). The coefficient on Business Dispersion is positive in all five regressions and statistically significant in three of five, indicating that in general firms with more disparate business unit operations have higher Cash ETRs. Again, we find that the effect of business segment dispersion on tax avoidance is mitigated for firms with better quality information, although the results are weaker than those found in panel A. Specifically, while the coefficients on the interaction term are negative using all five IIQ proxies, only two of the five are statistically significant. Overall, the results in table 3 are consistent with IIQ offsetting the negative effect of geographic and business segment dispersion on effective tax avoidance, and making coordination across all business units or subsidiaries possible.

\section{[Insert Table 3 here.]}

\subsection{Internal Information Quality, Uncertainty, and Tax Avoidance}

Table 4 examines whether firms with more uncertainty are less effective tax planners, and whether having better quality information moderates the impact of uncertainty on tax avoidance (hypotheses 3a and 3b). To examine this, we estimate equation 3 via OLS with Cash ETR as the tax avoidance proxy. Panel A contains the results of this estimation using Restructure as the

\footnotetext{
${ }^{38}$ It may be that firms with international operations have both more tax planning opportunities and higher internal information quality. However, the inclusion of a foreign income dummy and the level of foreign income scaled by total assets should mitigate these endogeneity concerns.
} 
uncertainty proxy, and panel B replaces Restructure with Sales Volatility. Again, for brevity we only report the coefficients on the IIQ proxy, the uncertainty proxy, and the interaction term.

The coefficient on Restructure in panel A indicates that firms undergoing restructuring have on average higher Cash ETRs, consistent with our prediction that these firms are undergoing periods of increased uncertainty which inhibits effective tax planning. The coefficient on the interaction term is significantly negative, implying that firms with better quality information are able to mitigate the effect of uncertainty on tax planning. In fact, the coefficient on the interaction term is generally larger than that on Restructure, suggesting that firms with the best quality information (top quintile of ranked IIQ proxies, no 404 material weaknesses) are able to achieve even lower Cash ETR during restructuring periods than in nonrestructuring periods. We speculate that firms that are undergoing restructuring are able to tap into new tax avoidance opportunities (for example through TESCM - tax-efficient supply chain management) that become visible only if they have a high quality information environment.

In panel B, we employ a measure of operating environment uncertainty, Sales Volatility. Again we find positive and significant (in four of five regressions) coefficients on our uncertainty proxy, demonstrating that operating environment uncertainty inhibits effective tax avoidance. Consistent with our predictions, the coefficient on the interaction of IIQ and Sales Volatility is negative using all five information proxies and statistically significant with three of the five. In general, the results in table 4 support our hypothesis that IIQ helps alleviate the negative effect of uncertainty on effective tax avoidance.

[Insert Table 4 here.]

\subsection{Internal Information Quality and Tax Risk}

Table 5 examines whether firms' budgeted tax risk varies with IIQ (hypothesis 4). Here, we repeat the estimation of equation 1 with our proxy for budgeted tax risk, UTB, as the dependent variable. Despite having fewer observations (as UTB is only available from 2007 onward), our regressions appear to have decent power. Many control variables are statistically significant and adjusted r-squared ranges from 0.16 to 0.26 . The coefficients on our information proxies are negative in four of the five regressions (EA Speed being the sole exception), and are statistically significant when using the two analyst-based proxies (Analyst Following and $A F$ $A c c$ ). Note also that sales volatility (as a measure of operating uncertainty) does not load 
significantly on UTB. More uncertainty does not mean that more tax risk is assumed, once controlling for IIQ. Overall, our results suggest that firms with better IIQ are able to achieve more favorable tax avoidance outcomes without assuming more risk, and perhaps are even able to reduce the level of risk taken. Controlling for IIQ, the link between ETR and UTB as proposed by Frischmann et al. (2008) is severed, since UTB now becomes a measure of tax risk assumed at the time of the tax filing (i.e. ex ante) rather than of tax avoidance.

[Insert Table 5 here.]

In table 6, we investigate whether firms with better quality information are able to minimize realized tax risk (hypothesis 5). To test this we estimate equation 1 with Cash ETR Volatility as our proxy for realized tax risk. Since this variable is measured over a five year period, we modify our IIQ proxies and control variables to be defined over the same 5-year period. Again, our models appear to have sufficient explanatory power, with adjusted r-squared ranging from 0.16 to 0.20 . We find that all five of our information proxies exhibit strong negative associations with Cash ETR Volatility. Moving from the bottom quintile to the top quintile in the ranked information proxies is associated with an average reduction in Cash ETR Volatility of 45 percent of the sample mean, and the absence of a section 404 material weakness is associated with a reduction of Cash ETR Volatility of 57 percent of the sample mean. Overall, the results in tables 5 and 6 indicate that firms with better quality information are able to achieve more favorable tax avoidance outcomes while also decreasing tax risk, both budgeted and realized.

[Insert Table 6 here.]

\section{ENDOGENEITY TESTS AND ROBUSTNESS}

In this section, we examine the robustness of our primary findings to a long-run specification, alternate tax avoidance proxies, correlated omitted variables and endogeneity issues, and alternate control variables.

\subsection{Long-run ETR}

In our primary tests we use a one-year version of Cash ETR as our dependent variable. However, Dyreng et al. (2008) argue that long-run measures of tax avoidance are superior to 
short-run measures in that they avoid variation in annual measures driven by timing differences and negative denominators. We investigate whether the results in table 1 are robust to using a longer-run measure of tax avoidance. Table 7 contains the results of estimating equation 1 with the five-year cash effective tax rate (Cash ETR5) as the dependent variable. Similar to table 6, we redefine our IIQ proxies and control variables to match the five-year period over which the dependent variable is measured. The coefficient on our IIQ proxies is consistently negative and statistically significant. Moving from bottom quintile to the top quintile in our IIQ proxies in each of the five years is associated with reductions in Cash ETR5 ranging from 4 percent to 10 percent, and not having a section 404 material weakness in any year of the five year period is associated with a reduction in the five-year cash effective tax rate of 7 percent. The results in table 7 indicate that our primary results are robust, both statistically and economically, to using longer-run measures of tax avoidance.

\section{[Insert Table 7 here.]}

Dyreng et al. (2008) present interesting (but unexplained - see footnote 21) results on the persistence of ETRs: low ETRs are more persistent than high ETRs. In conjunction with our results on Cash ETR Volatility, our focus on IIQ begins to address such explanation, since we find that higher IIQ leads both to lower ETRs and to lower ETR volatility, which ensures that such lower ETRs persist. ${ }^{39}$

\subsection{Alternate tax avoidance proxies}

As discussed earlier, we employ the firm's cash effective tax rate as our primary measure of tax avoidance in order to avoid any mechanical relations between our tax avoidance proxy and IIQ variables, some of which involve forecasting accounting earnings. Additionally, a commonly used alternate measure of tax avoidance, the book effective tax rate or GAAP ETR, is increased when a liability for uncertain tax positions is recorded, at which point a mechanical correlation between GAAP ETR and UTB (our measure of budgeted tax risk) is created. Nevertheless, we investigate the sensitivity of our results to two alternative proxies for tax avoidance that do have a more important accounting accrual aspect: the firm's book effective tax rate (GAAP ETR,

\footnotetext{
${ }^{39}$ Guenther et al. (2012) document that low ETR volatility and low ETR are correlated, arguing that hence both measures cannot be capturing the same concept of tax avoidance. However, they do not explain what could cause such positive correlation. We propose IIQ as a causal factor.
} 
measured as the current tax expense divided by pre-tax income) and book-tax difference (BTD, measured as pre-tax book income minus estimated taxable income, scaled by average total assets). When we regress annual levels, annual changes, volatility, and five-year levels of both alternate tax avoidance proxies on the five IIQ proxies, untabulated results show that 85 and 65 percent of the coefficients are statistically significant with the predicted sign on GAAP ETR and $B T D$, respectively. ${ }^{40}$ We also investigate the effects of IIQ on firms with higher coordination needs and more uncertainty employing GAAP ETR and BTD as the tax planning proxies. Untabulated results show that, when using GAAP ETR, we find similar results to those found in tables 3 and 4, with stronger results on business dispersion and restructuring, but weaker results on sales volatility. However, results with $B T D$ are weaker throughout tables 3 and 4 . We conclude that our inferences are robust to these two alternate measures of tax avoidance. Furthermore, our results suggest that higher IIQ allows managers to avoid more taxes for both cash and book purposes.

\subsection{Correlated omitted variables and endogeneity}

Our results are consistent with the notion that IIQ is driving the firm's tax avoidance outcomes. However, it may be the case that there are other variables that are correlated with both the presence of a high quality internal information environment and tax avoidance opportunities. Furthermore, if IIQ and tax avoidance are both choices on the part of the firm, our analyses may suffer from endogeneity. In this section we attempt to rule out correlated omitted variables and endogeneity as potential concerns.

First, we include an expansive set of control variables that could capture differences in both IIQ and tax avoidance opportunities across firms. For example, it is likely that certain industries and firms with international operations have better quality internal information and more tax avoidance opportunities. Thus, we directly control for industry membership (through industry fixed effects) and international operations (through a foreign income dummy and the level of foreign income scaled by assets) in our regressions.

Second, since there are likely unobservable firm characteristics for which we cannot include controls in our analyses, we also estimate our primary regression in first differences. This

\footnotetext{
${ }^{40}$ We repeat the analyses in tables 2 (levels), 6 (volatility), 7 (long-run) and 8 (changes), and find that 17/20 and $13 / 20$ coefficients, respectively, to be significant with the predicted sign.
} 
should remove the effect of these unobservable firm characteristics that are constant across time. The results of estimating a changes model (with $\triangle$ Cash ETR as the dependent variable) are presented in table 8. For brevity, we only report the coefficient on the changes in our IIQ proxies. The coefficient on the change in IIQ is negative for all five proxies, and is statistically significant when using $\triangle E A$ Speed, $\triangle M F A c c$, and $\triangle A F$ Acc. The insignificance of the coefficients on $\triangle N o$ $M W$ and $\triangle$ Analyst Following is likely caused by the lack of observed changes in these variables: only 8 percent of observations with non-missing $\triangle N o M W$ and only 38 percent of observations with non-missing 4 Analyst Following have non-zero changes, compared to 35 percent, 62 percent, and 70 percent for $\triangle E A$ Speed, $\triangle M F A c c$, and $\triangle A F A c c$, respectively. The results in table 8 rule out the possibility that our IIQ proxies are capturing a correlated omitted variable that is constant across time. Furthermore, they suggest that changes in the firm's IIQ affect its ability to avoid taxes.

\section{[Insert Table 8 here].}

Third, we re-estimate the analysis in table 2 replacing the current year's Cash ETR with the next year's Cash ETR, thus examining whether the proxies for the current quality of the internal information environment can help predict tax avoidance in the subsequent year. Untabulated results show a significant negative relation between all five IIQ proxies and next year's Cash ETR.

Fourth, we rely on a shock to the quality of the internal information environment of the firm: the enactment of Sarbanes-Oxley. Sarbanes-Oxley required firms to assess the adequacy of their internal controls on financial reporting and disclose whether they had a material weakness. Thus, the act brought negative attention to firms that had to initially disclose a material weakness, possibly forcing them to focus on improving their IIQ. We examine whether firms that initially disclosed a section 404 material weakness after the implementation of Sarbanes-Oxley and subsequently remedied the material weakness display lower Cash ETRs after remedying their material weakness compared to all other firms. To test this, we employ a differences-indifferences design: we regress Cash ETR on an indicator variable equaling one for firms that initially disclosed a section 404 material weakness in 2004 but remedied it immediately (that is, failed to disclose a $404 \mathrm{MW}$ after 2004), an indicator variable equaling one for the years 2005 and 2006, and the interaction of these two variables. We run this test over the period 2002 to 
2006 (which captures two years before the initial disclosure, the year of initial disclosure, and two years afterward) and include the full set of control variables. We find that the coefficient on the interaction term is negative and statistically significant (-0.046, one-tailed p-value of 0.029), suggesting that those firms that improved their internal information environment post the shock imposed by Sarbanes-Oxley experienced an economically meaningful reduction in their Cash ETR relative to other firms.

We believe that including our extensive set of control variables, the consistency of our results when employing both a first-differences specification as well as next period's Cash ETR rather than current period's Cash ETR as the dependent variable, and showing the effect of the shock to firms' information environment caused by Sarbanes-Oxley on tax avoidance suggest that correlated omitted variables and endogeneity are not responsible for our results.

\subsection{Alternate control variables}

Although we already use a very extensive set of controls, we also investigate the sensitivity of our results to several potential additional control variables. First, it may be the case that our IIQ measures simply pick up firms that have less volatile income streams, which likely affects tax avoidance outcomes. We include Pre-tax Income Volatility (standard deviation of pretax income over the current five year period, scaled by median total assets over the same period) as a proxy for earnings smoothness. Untabulated results show that the IIQ proxies are still negatively and significantly associated with Cash ETR and Cash ETR Volatility, even after controlling for the smoothness of the pre-tax earnings.

We also include the following additional control variables: Asset Growth (current assets minus lagged assets, scaled by lagged assets), Inventory (average inventory divided by average total assets), Advertising (advertising expenses divided by average total assets), Special Items (special items divided by total assets), Stock Return Volatility (standard deviation of stock returns over current twelve months), and Sales Growth Volatility (standard deviation of sales growth over the current five year period). Our inferences are unchanged when including these additional variables in our regressions. 


\section{CONCLUSION AND FURTHER RESEARCH}

Our paper takes an important step towards unraveling the black box of tax avoidance by studying the role the internal information environment of the firm plays in supporting effective tax planning resulting in increased tax avoidance via the mechanisms of (1) resolution of uncertainty through information acquisition, (2) coordination through information dissemination and (3) reduction of tax outcome risk, both budgeted and actual. Only by disentangling the risk aspect from the tax avoidance measure by understanding the quality of the information on which tax planning decisions are based, can we really understand and define what it means to exhibit tax (non)aggressiveness. Further, our findings demonstrate the importance of building bridges between managerial accounting and taxation research.

We see a lot of avenues for further research. First, using our proxies for internal information quality, subsequent studies can further disentangle which variables affect the tax risk (both budgeted and actual) and which variables affect tax avoidance conditional on such risk. For example, it may well be that high IIQ firms do not need to enter more risky tax shelter constructions if they are able to achieve a low (enough) ETR without assuming much risk. Also, the market's perception of tax avoidance may be different for firms with high versus low IIQ. Second, recent research has started to look at how performance measurement and incentives internally in the firm affect taxation outcomes (e.g. Armstrong et al., 2012; Phillips, 2003; Robinson et al., 2010). Future research can address how other aspects of managerial accounting impact on taxation. For example, it is feasible that the quality of the budgeting process, the match between organizational and informational design, and the precision by which performance measurement information is collected all affect the quality of tax planning decisions. Lastly, although our focus in this paper is on tax avoidance, IIQ affects a lot of other aspects of decision making in the firm, such as procurement, capital investment decisions, production and project planning, product or service mix choices, customer mix choices, and the like. New insights can be generated into how the quality of such decisions and their outcomes is based on the quality of the internal information environment. With optimism fueled by the resurgence of academic interest in bridging between different areas of accounting research, we look forward to work that addresses the above issues. 


\section{REFERENCES}

Abernethy, M. A., and Bouwens, J. (2005). Determinants of Accounting Innovation Implementation. Abacus, 41(3), 217-240.

Anderson, S. W. (1995). A Framework for Assessing Cost Management System Changes: The Case of Activity Based Costing Implementation at General Motors, 1986-1993. Journal of Management Accounting Research, 7, 1-51.

Argyris, C., and Kaplan, R. S. (1994). Implementing New Knowledge: The Case of ActivityBased Costing. Accounting Horizons, 8(3), 83-105.

Armstrong, C. S., Blouin, J. L., and Larcker, D. F. (2012). The Incentives for Tax Planning. Journal of Accounting and Economics, 53, 391-411.

Baginski, S. P., and Hassell, J. M. (1997). Determinants of Management Forecast Precision. The Accounting Review, 72(2), 303-312.

Balakrishnan, K., Blouin, J. L., and Guay, W. (2011). Does Tax Aggressiveness Reduce Financial Reporting Transparency? Working Paper.

Balakrishnan, R., Hansen, S., and Labro, E. (2011). Evaluating Heuristics Used When Designing Product Costing Systems. Management Science, 57(3), 520-541.

Bauer, A. (2011). Internal Control Quality as an Explanatory Factor of Tax Avoidance. Working Paper.

Beck, P. J., Davis, J. S., and Jung, W.-O. (1996). Tax Advice and Reporting under Uncertainty: Theory and Experimental Evidence. Contemporary Accounting Research, 13(1), 49-80.

Beyer, A., Cohen, D. A., Lys, T. Z., and Walther, B. R. (2010). The Financial Reporting Environment: Review of the Recent Literature. Journal of Accounting and Economics, 50, 296-343.

Blouin, J. L., Devereux, M., and Shackelford, D. A. (2012). Investment, Tax Uncertainty, and Aggressive Tax Avoidance. Working Paper.

Bowen, R., Davis, A., and Matsumoto, D. (2002). Do Conference Calls Affect Analysts' Forecasts? The Accounting Review, 77, 285-316.

Brazel, J. F., and Dang, L. (2008). The Effect of ERP System Implementations on the Management of Earnings and Earnings Release Dates. Journal of Information Systems, 22(2), $1-21$.

Burns, J., and Scapens, R. W. (2000). Conceptualizing management accounting change: an institutional framework. Management Accounting Research, 11, 3-25.

Bushman, R. M., Indjejikian, R. J., and Smith, A. (1995). Aggregate Performance Measures in Business Unit Manager Compensation: The Role of Intrafirm Interdependencies. Journal of Accounting Research, 33, 101-128.

Cassar, G., and Gibson, B. (2008). Budgets, Internal Reports, and Manager Forecast Accuracay. Contemporary Accounting Research, 25(3), 707-737.

CFOResearchServices. (2010). Accelerating the Financial Close. CFOs' Insights into the Benefits of a High-Quality Close. . CFO Publishing LLC.

Chapman, C. S., and Kihn, L.-A. (2009). Information System Integration, Enabling Control and Performance. Accounting, Organizations and Society, 34, 151-169.

Chasan, E. (2012, July 23, 2012). The Financial-Data Dilemma, Wall Street Journal.

Cheng, A., Huang, H. H., Li, Y., and Stanfield, J. (2012). The Effect of Hedge Fund Activism on Corporate Tax Avoidance. The Accounting Review. 
Chenhall, R. H. (2008). Accounting for the Horizontal Organization. In C. S. Chapman, A. Hopwood \& M. D. Shields (Eds.), Handbook of Management Accounting Research (Vol. 3, pp. 1207-1234): Elsevier.

Chenhall, R. H., and Morris, D. (1986). The Impact of Structure, Environment, and Interdependence on the Perceived Usefulness of Management Accounting Systems. The Accounting Review, 61(1), 16-35.

Coller, and Yohn, T. (1998). Management Forecasts: What Do We Know? Financial Analysts Journal, Jan/Feb, 58-62.

Cranford, S., Murias, F., and Schutzman, M. (2012). Elevating Tax Department Productivity with an "Efficiency Dividend". Corporate Tax Management.

Desai, M. A., and Dharmapala, D. (2006). Corporate Tax Avoidance and High-Powered Incentives. Journal of Financial Economics, 79(1), 145-179.

Dhaliwal, D. S., Gleason, C. A., and Mills, L. F. (2004). Last-Chance Earnings Management: Using the Tax Expense to Meet Analysts' Forecasts. Contemporary Accounting Research, 21(2), 431-459.

Dichev, I., Graham, J., Harvey, C. R., and Rajgopal, S. (2012). Earnings Quality: Evidence from the Field. Paper presented at the Journal of Accounting and Economics Conference.

Dorantes, C.-A., Li, C., Peters, G. F., and Richardson, V. J. (2012, forthcoming). The Effect of Enterprise Systems Implementations on the Firm Information Environment. Contemporary Accounting Research.

Dyreng, S. D., Hanlon, M., and Maydew, E. L. (2008). Long-Run Corporate Tax Avoidance. The Accounting Review, 83(1), 61-82.

Dyreng, S. D., Hanlon, M., and Maydew, E. L. (2010). The Effects of Executives on Corporate Tax Avoidance. The Accounting Review, 85, 1163-1189.

Dyreng, S. D., and Lindsey, B. P. (2009). Using Financial Accounting Data to Examine the Effect of Foreign OPerations Located in Tax Havens and Other Countries on U.S. Multinational Firms' Tax Rates. Journal of Accounting Research, 47(5), 1283-1316.

Ernst, and Young. (2010). Global Transfer Pricing Survey: Addressing the Challenges of Globalization. [Whitepaper].

Ernst, and Young. (2011). Managing Global Tax Reporting Challenges. [Whitepaper].

Feng, M., and Koch, A. S. (2010). Once Bitten, Twice Shy: The Relation between Outcomes of Earnings Guidance and Management Guidance Strategy. The Accounting Review, 85(6), 1951-1984.

Feng, M., Li, C., and McVay, S. (2009). Internal Control and Management Guidance. Journal of Accounting and Economics, 48, 190-209.

Francis, J., Hanna, D. J., and Philbrick, D. R. (1997). Management Comminications with Securities Analysts. Journal of Accounting and Economics, 24(363-394).

Frank, M. M., and Rego, S. O. (2006). Do Managers Use the Valuation Allowance Account to Manage Earnings around Certain Earnings Targets? Journal of the American Taxation Association, 28(1), 43-65.

Frischmann, P. J., Shevlin, T., and Wilson, R. (2008). Economic Consequences of Increasing the Conformity in Accounting for Uncertain Tax Benefits. Journal of Accounting and Economics, 46, 261-278.

Galbraith, J. R. (1974). Organization Design: An Information Processing View. Interfaces, 4(3), 28-36.

Ghosh, S. (2002). Challenges on a global implementation of ERP software. IEEE, 101-105. 
Gong, G., Li, L. Y., and Xie, H. (2009). The Association between Management Earnings Forecast Errors and Accruals. The Accounting Review, 84(2), 497-530.

Guenther, D. A., Matsunaga, S. R., and Williams, B. M. (2012). Corporate Tax Aggressiveness and Firm Risk. Working Paper.

Gupta, S., and Newberry, K. (1997). Determinants of the Variability in Corporate Effective Tax Rates: Evidence from Longitudinal Data. Journal of Accounting and Public Policy, 16, 1-34.

Hanlon, M. (2012). Tax Research, slides presented at American Accounting Association Doctoral Consortium. Lake Tahoe.

Hanlon, M., and Heitzman, S. (2010). A Review of Tax Research. Journal of Accounting and Economics, 50, 127-178.

Hemmer, T., and Labro, E. (2008). On the Optimal Relation between the Properties of Managerial and Financial Reporting Systems. Journal of Accounting Research, 46(5), 12091240.

Hodge, F. D., Kennedy, J. J., and Mains, L. A. (2004). Does Search-Facilitating Technology Improve the Transparency of Financial Reporting? The Accounting Review, 79(3), 687-703.

Horngren, C. T., Datar, S. M., Foster, G., Rajan, M., and Ittner, C. D. (2012). Cost Accounting: $a$ Managerial Emphasis: Pearson Prentice Hall.

Ittner, C. D., Lanen, W. N., and Larcker, D. F. (2002). The Association Between Activity-Based Costing and Manufacturing Performance. Journal of Accounting Research, 40(3), 711-726.

Ittner, C. D., and Larcker, D. F. (2001). Assessing Empirical Research in Managerial Accounting: a Value-Based Management Perspective. Journal of Accounting and Economics, 32, 349-410.

Jennings, J., Stoumbos, R., and Tanlu, L. (2012). The Effect of Organizational Complexity on Earnings Forecasting Behavior. Working Paper.

Jung, W.-O., and Kwon, Y. K. (1988). Disclosure when the Market is Unsure of Information Endowment of Managers. Journal of Accounting Research, 26(1), 146-153.

Klotsche, J., and Traubenberg, N. (2010, January 11). Tax Risk Management: Shulman's Conversation with the Board. Tax Notes, 126.

Labro, E., and Vanhoucke, M. (2007). A Simulation Analysis of Interactions among Errors in Costing Systems. The Accounting Review, 82(4), 939-962.

Lang, M. H., and Lundholm, R. J. (1996). Corporate Disclosure Policy and Analyst Behavior. The Accounting Review, 71(4), 467-492.

Li, C., Peters, G. F., Richardson, V. J., and Weidenmier, M. W. (2012). The Consequences of Information Technology Control Weaknesses on Management Information Systems: The Case of Sarbanes-Oxley Internal Control Reports. MIS Quarterly, 36(1), 179-203.

Luo, Y. (2005). Do Insiders Learn from Outsiders? Evidence from Mergers and Acquisitions. Journal of Finance, 60, 1951-1982.

Maiga, A. S., and Jacobs, F. A. (2008). Extent of ABC Use and Its Consequences. Contemporary Accounting Research, 25(2), 533-566.

Major, M., and Hopper, T. (2005). Managers divided: Implementing ABC in a Portuguese telecommunications company. Management Accounting Research, 16, 205-229.

Masli, A., Peters, G. F., Richardson, V. J., and Sanchez, J. M. (2010). Examining the Potential Benefits of Internal Control Monitoring Technology. The Accounting Review, 85(3), 10011034.

Maydew, E. L. (2001). Empirical Tax Research in Accounting: A Discussion. Journal of Accounting and Economics, 31, 389-403. 
McGuire, S. T., Neuman, S. S., and Omer, T. C. (2011). Through the Looking Glass: Are Sustainable Tax Strategies Reflected in Earnings Persistence? Working Paper.

McGuire, S. T., Omer, T. C., and Wilde, J. H. (2012). Investment Opportunity Sets, Operating Uncertainty, and Capital Market Pressure: Determinants of Investments in Tax Shelter Acitivities? Working Paper. Texas A\&M University.

McKinnon, J. D. (2012). Firms Pass Up Tax Breaks, Citing Hassles, Complexity. [Newspaper]. Wall Street Journal.

Mills, L. F., Erickson, M. M., and Maydew, E. L. (1998). Investments in Tax Planning. Journal of the American Taxation Association, 20(1), 1-20.

Mills, L. F., Robinson, L. A., and Sansing, R. C. (2010). FIN 48 and Tax Compliance. The Accounting Review, 85(5), 1721-1742.

Morris, J. J. (2011). The Impact of Enterprise Resource Planning (ERP) Systems on the Effectiveness of Internal Controls over Financial Reporting. Journal of Information Systems, 25(1), 129-157.

Phillips, J. D. (2003). Corporate Tax-Planning Effectiveness: The Role of Compensation-Based Incentives. The Accounting Review, 78(3), 847-874.

PriceWaterhouseCoopers. (2012). Assessing Tax: 2012 Tax Rate Benchmarking Study for Industrial Products and Services Companies.

Rego, S. (2003). Tax Avoidance of U.S. Multinational Corporations. Contemporary Accounting Research, 20, 805-833.

Rego, S., and Wilson, R. (2012). Equity Risk Incentives and Corporate Tax Aggressiveness. Journal of Accounting Research, 50(3), 775-810.

Robinson, J. R., Sikes, S. A., and Weaver, C. D. (2010). Performance Measurement of Corporate Tax Departments. The Accounting Review, 85(3), 1035-1064.

Rossing, C. P., and Rohde, C. (2010). Overhead Cost Allocation Changes in a Transfer Pricing Tax Compliant Multinational Enterprise. Management Accounting Research, 21, 199-216.

Scapens, R. W., and Roberts, J. (1993). Accounting and Control: a Case Study of Resistance to Accounting Change. Management Accounting Research, 4, 1-32.

Schrand, C. M., and Wong, M. H. F. (2003). Earnings Management Using the Valuation Allowance for Deferred Tax Assets under SFAS No. 109. Contemporary Accounting Research, 20(3), 579-611.

Schreuder, H., and Klaassen, J. (1984). Confidential Revenue and Profit Forecasts by Management and Financial Analysts: Evidence from the Netherlands. The Accounting Review, 59(1), 64-76.

Scotchmer, S., and Slemrod, J. (1989). Randomness in Tax Enforcement. Journal of Public Economics, 38(1), 17-32.

Shackelford, D. A., and Shevlin, T. (2001). Empirical Tax Research in Accounting. Journal of Accounting and Economics, 31, 321-387.

Shields, M. D. (1995). An Empirical Analysis of Firms' Implementation Experiences with Activity-Based Costing. Journal of Management Accounting Research, 7, 148-166.

Stoumbos, R. C., and Tanlu, L. (2009). Are Managers Unable or Unwilling to Revise Earnings Forecasts? Working Paper.

Verrecchia, R. E. (1990). Information Quality and Discretionary Disclosure. Journal of Accounting and Economics, 12, 365-380.

Viglione, J. A., and Norton, B. (2009, February 28). The Growing Convergence of Finance and Tax - What it Means for the Future of Tax Technology. The Tax Executive. 
Williams, P. (1996). The Relation Between Prior Earnings Forecast by Management and Analyst Response to a Current Management Forecast. The Accounting Review, 71, 103-116.

Zhigang, Q. (2010). Tax Auditing in Enterprise Resource Planning (ERP) Systems: the Influence and Countermeasures. Advanced Materials Research, 129-131, 490-494. 


\section{APPENDIX: VARIABLE DEFINITIONS}

Dependent Variables

Cash ETR

Cash ETR Volatility

UTB

Internal Information

Quality (IIQ) Variables

EA Speed

MF Acc

No $M W$

Analyst Following

AF Acc
Descriptions

Cash taxes paid, divided by pre-tax income adjusted for special items

Standard deviation of Cash ETR over current 5-year period

Average unrecognized tax benefit, divided by average total assets 
TABLE 1: DESCRIPTIVE STATISTICS AND CORRELATIONS

Panel A: Descriptive Statistics

\begin{tabular}{|c|c|c|c|c|c|c|c|c|}
\hline Variables & $\mathbf{N}$ & Mean & $\begin{array}{l}\text { Std } \\
\text { Dev }\end{array}$ & Min & $\begin{array}{l}\text { 25th } \\
\text { Pctl }\end{array}$ & Median & $\begin{array}{l}\text { 75th } \\
\text { Pctl }\end{array}$ & Max \\
\hline Cash ETR & 35167 & 0.26 & 0.21 & 0.00 & 0.10 & 0.25 & 0.36 & 1.00 \\
\hline Cash ETR Volatility & 22316 & 0.12 & 0.09 & 0.01 & 0.06 & 0.09 & 0.16 & 0.42 \\
\hline UTB & 6626 & 0.01 & 0.02 & 0.00 & 0.00 & 0.01 & 0.02 & 0.13 \\
\hline EA Speed & 48536 & -46.67 & 20.97 & -132.00 & -57.00 & -43.00 & -31.00 & -16.00 \\
\hline$M F A c c$ & 10321 & -0.02 & 0.06 & -0.45 & -0.01 & 0.00 & 0.00 & 0.00 \\
\hline No MW & 15874 & 0.93 & 0.26 & 0.00 & 1.00 & 1.00 & 1.00 & 1.00 \\
\hline Analyst Following & 48862 & 1.42 & 1.00 & 0.00 & 0.69 & 1.39 & 2.20 & 3.37 \\
\hline$A F A c c$ & 48072 & -0.10 & 0.51 & -4.37 & -0.01 & 0.00 & 0.00 & 0.00 \\
\hline Geographic Dispersion & 44158 & 0.23 & 0.26 & 0.00 & 0.00 & 0.10 & 0.47 & 0.80 \\
\hline Business Dispersion & 47202 & 0.19 & 0.26 & 0.00 & 0.00 & 0.00 & 0.44 & 0.79 \\
\hline Restructure & 49642 & 0.19 & 0.39 & 0.00 & 0.00 & 0.00 & 0.00 & 1.00 \\
\hline Sales Volatility & 46341 & 0.29 & 0.31 & 0.01 & 0.10 & 0.20 & 0.36 & 1.92 \\
\hline Size & 49642 & 5.95 & 1.87 & 1.44 & 4.57 & 5.82 & 7.21 & 10.46 \\
\hline$P P E$ & 49642 & 0.28 & 0.24 & 0.01 & 0.09 & 0.20 & 0.41 & 0.89 \\
\hline$\triangle P P E$ & 49642 & 0.03 & 0.09 & -0.23 & -0.01 & 0.01 & 0.04 & 0.44 \\
\hline Leverage & 49642 & 0.18 & 0.19 & 0.00 & 0.01 & 0.14 & 0.30 & 0.83 \\
\hline Intangibles & 49642 & 0.13 & 0.17 & 0.00 & 0.00 & 0.05 & 0.20 & 0.70 \\
\hline RED Expense & 49642 & 0.06 & 0.11 & 0.00 & 0.00 & 0.00 & 0.07 & 0.61 \\
\hline NOL Dummy & 49642 & 0.34 & 0.47 & 0.00 & 0.00 & 0.00 & 1.00 & 1.00 \\
\hline$\triangle N O L$ & 49642 & 0.04 & 0.19 & -0.45 & 0.00 & 0.00 & 0.00 & 1.31 \\
\hline Extraordinary Items & 49642 & 0.00 & 0.02 & -0.12 & 0.00 & 0.00 & 0.00 & 0.07 \\
\hline Foreign Income & 49642 & 0.01 & 0.03 & -0.08 & 0.00 & 0.00 & 0.00 & 0.13 \\
\hline FI Dummy & 49642 & 0.37 & 0.48 & 0.00 & 0.00 & 0.00 & 1.00 & 1.00 \\
\hline$R O A$ & 49642 & 0.08 & 0.20 & -0.91 & 0.05 & 0.12 & 0.18 & 0.43 \\
\hline MTB & 49642 & 3.00 & 3.84 & -10.67 & 1.35 & 2.16 & 3.61 & 23.93 \\
\hline Sales Growth & 49642 & 0.21 & 0.57 & -0.77 & -0.01 & 0.10 & 0.26 & 4.17 \\
\hline Age & 49642 & 2.44 & 0.90 & 0.69 & 1.79 & 2.40 & 3.18 & 4.03 \\
\hline
\end{tabular}




\section{Panel B: Correlations}

\begin{tabular}{|c|c|c|c|c|c|c|c|c|c|c|c|c|c|}
\hline & Variable & 1 & 2 & 3 & 4 & 5 & 6 & 7 & 8 & 9 & 10 & 11 & 12 \\
\hline 1 & Cash ETR & & 0.26 & -0.05 & -0.03 & -0.13 & -0.05 & -0.05 & -0.01 & -0.01 & 0.01 & -0.03 & 0.04 \\
\hline 2 & Cash ETR Volatility & 0.11 & & -0.01 & -0.16 & -0.15 & -0.08 & -0.18 & -0.05 & 0.03 & 0.03 & 0.05 & 0.01 \\
\hline 3 & UTB & -0.01 & -0.05 & & 0.10 & 0.00 & -0.01 & -0.01 & -0.01 & 0.21 & -0.02 & 0.16 & -0.04 \\
\hline 4 & EA Speed & 0.00 & -0.16 & 0.26 & & 0.18 & 0.30 & 0.44 & 0.22 & 0.17 & 0.08 & 0.06 & -0.06 \\
\hline 5 & $M F A c c$ & -0.05 & -0.16 & 0.09 & 0.17 & & 0.10 & 0.19 & 0.39 & 0.05 & 0.06 & -0.04 & -0.05 \\
\hline 6 & No $M W$ & -0.02 & -0.06 & 0.02 & 0.20 & 0.11 & & 0.13 & 0.07 & -0.03 & 0.00 & -0.03 & -0.04 \\
\hline 7 & Analyst Following & -0.02 & -0.19 & 0.14 & 0.45 & 0.27 & 0.13 & & 0.20 & 0.17 & 0.12 & 0.06 & -0.02 \\
\hline 8 & $A F A c c$ & 0.02 & -0.21 & 0.07 & 0.36 & 0.58 & 0.13 & 0.47 & & 0.04 & 0.05 & -0.02 & -0.01 \\
\hline 9 & Geographic Dispersion & -0.03 & 0.01 & 0.33 & 0.19 & 0.08 & -0.03 & 0.17 & 0.10 & & 0.17 & 0.30 & -0.12 \\
\hline 10 & Business Dispersion & 0.00 & 0.04 & 0.08 & 0.08 & 0.08 & 0.00 & 0.12 & 0.09 & 0.18 & & 0.16 & -0.08 \\
\hline 11 & Restructure & -0.06 & 0.05 & 0.24 & 0.06 & 0.00 & -0.03 & 0.06 & -0.04 & 0.30 & 0.15 & & -0.11 \\
\hline 12 & Sales Volatility & 0.08 & 0.01 & -0.04 & -0.06 & -0.07 & -0.03 & -0.04 & 0.03 & -0.08 & -0.08 & -0.12 & \\
\hline
\end{tabular}

This table presents descriptive statistics for the variables used in our analyses. Panel A presents descriptive statistics for the sample and Panel B presents the Pearson (above diagonal) and Spearman (below diagonal) correlations. The sample is composed of all observations with non-missing data for control variables and at least one IIQ proxy. All variables are defined in the appendix. For the purposes of this table, the IIQ proxies are presented in their unranked form. All continuous variables are winsorized at the $1^{\text {st }}$ and $99^{\text {th }}$ percentiles, except ETRs, which are winsorized at 0 and 1 . 
TABLE 2: INTERNAL INFORMATION QUALITY AND TAX AVOIDANCE

\begin{tabular}{|c|c|c|c|c|c|c|}
\hline VARIABLES & $\begin{array}{l}\text { IIQ Proxy: } \\
\text { Dep Var: }\end{array}$ & $\begin{array}{l}\text { EA Speed } \\
\text { Cash ETR }\end{array}$ & $\begin{array}{c}\text { MF Acc } \\
\text { Cash ETR }\end{array}$ & $\begin{array}{c}\text { No MW } \\
\text { Cash ETR }\end{array}$ & $\begin{array}{c}\text { Analyst Foll } \\
\text { Cash ETR }\end{array}$ & $\begin{array}{c}\text { AF Acc } \\
\text { Cash ETR }\end{array}$ \\
\hline$I I Q$ & $\begin{array}{l}\text { Pred } \\
\text { Sign: - }\end{array}$ & $\begin{array}{c}-0.026^{* * *} \\
(-4.835)\end{array}$ & $\begin{array}{c}-0.036^{* * *} \\
(-5.408)\end{array}$ & $\begin{array}{c}-0.052^{* * *} \\
(-4.608)\end{array}$ & $\begin{array}{c}-0.022^{* * *} \\
(-3.485)\end{array}$ & $\begin{array}{r}-0.041^{* * *} \\
(-8.302)\end{array}$ \\
\hline Size & & $\begin{array}{l}0.003^{* *} \\
(1.979)\end{array}$ & $\begin{array}{c}-0.003 \\
(-1.446)\end{array}$ & $\begin{array}{c}-0.002 \\
(-0.948)\end{array}$ & $\begin{array}{l}0.004^{* *} \\
(2.380)\end{array}$ & $\begin{array}{l}0.003^{* *} \\
(2.264)\end{array}$ \\
\hline$P P E$ & & $\begin{array}{c}-0.045^{* * *} \\
(-3.453)\end{array}$ & $\begin{array}{c}0.005 \\
(0.192)\end{array}$ & $\begin{array}{c}-0.010 \\
(-0.471)\end{array}$ & $\begin{array}{r}-0.047^{* * *} \\
(-3.647)\end{array}$ & $\begin{array}{c}-0.047^{* * *} \\
(-3.601)\end{array}$ \\
\hline$\triangle P P E$ & & $\begin{array}{c}-0.028 \\
(-1.400)\end{array}$ & $\begin{array}{l}-0.092^{*} \\
(-1.780)\end{array}$ & $\begin{array}{l}-0.086^{* *} \\
(-2.165)\end{array}$ & $\begin{array}{c}-0.017 \\
(-0.835)\end{array}$ & $\begin{array}{c}-0.014 \\
(-0.678)\end{array}$ \\
\hline Leverage & & $\begin{array}{c}-0.101^{* * *} \\
(-7.045)\end{array}$ & $\begin{array}{c}-0.085^{* * *} \\
(-3.293)\end{array}$ & $\begin{array}{c}-0.097^{* * *} \\
(-4.986)\end{array}$ & $\begin{array}{c}-0.101^{* * *} \\
(-7.101)\end{array}$ & $\begin{array}{r}-0.108^{* * *} \\
(-7.532)\end{array}$ \\
\hline Intangibles & & $\begin{array}{c}0.023^{*} \\
(1.751)\end{array}$ & $\begin{array}{c}0.020 \\
(1.042)\end{array}$ & $\begin{array}{c}0.030^{*} \\
(1.647)\end{array}$ & $\begin{array}{c}0.024^{*} \\
(1.856)\end{array}$ & $\begin{array}{l}0.031^{* *} \\
(2.365)\end{array}$ \\
\hline RED Expense & & $\begin{array}{c}-0.282^{* * *} \\
(-8.106)\end{array}$ & $\begin{array}{c}-0.325^{* * *} \\
(-4.984)\end{array}$ & $\begin{array}{c}-0.297^{* * *} \\
(-4.867)\end{array}$ & $\begin{array}{c}-0.293^{* * *} \\
(-8.495)\end{array}$ & $\begin{array}{c}-0.307^{* * *} \\
(-8.945)\end{array}$ \\
\hline NOL Dummy & & $\begin{array}{c}-0.036^{* * *} \\
(-9.635)\end{array}$ & $\begin{array}{c}-0.022^{* * *} \\
(-3.938)\end{array}$ & $\begin{array}{c}-0.027^{* * *} \\
(-5.159)\end{array}$ & $\begin{array}{c}-0.036^{* * *} \\
(-9.643)\end{array}$ & $\begin{array}{c}-0.037^{* * *} \\
(-9.954)\end{array}$ \\
\hline$\triangle N O L$ & & $\begin{array}{c}0.019 \\
(1.019)\end{array}$ & $\begin{array}{l}0.075^{* *} \\
(2.117)\end{array}$ & $\begin{array}{c}0.021 \\
(0.815)\end{array}$ & $\begin{array}{c}0.019 \\
(0.992)\end{array}$ & $\begin{array}{c}0.017 \\
(0.874)\end{array}$ \\
\hline Extraordinary Items & & $\begin{array}{c}0.978^{* * *} \\
(8.061)\end{array}$ & $\begin{array}{c}0.906^{* * *} \\
(4.197)\end{array}$ & $\begin{array}{c}1.298^{* * *} \\
(4.390)\end{array}$ & $\begin{array}{c}0.977^{* * *} \\
(8.099)\end{array}$ & $\begin{array}{c}0.990^{* * *} \\
(8.084)\end{array}$ \\
\hline Foreign Income & & $\begin{array}{c}-0.340^{* * *} \\
(-5.046)\end{array}$ & $\begin{array}{c}-0.125 \\
(-1.313)\end{array}$ & $\begin{array}{c}-0.386^{* * *} \\
(-4.397)\end{array}$ & $\begin{array}{c}-0.339^{* * *} \\
(-4.994)\end{array}$ & $\begin{array}{c}-0.327^{* * *} \\
(-4.811)\end{array}$ \\
\hline FI Dummy & & $\begin{array}{c}0.034^{* * *} \\
(7.819)\end{array}$ & $\begin{array}{c}0.022^{* * *} \\
(3.380)\end{array}$ & $\begin{array}{c}0.036^{* * *} \\
(5.313)\end{array}$ & $\begin{array}{c}0.033^{* * *} \\
(7.773)\end{array}$ & $\begin{array}{c}0.033^{* * *} \\
(7.772)\end{array}$ \\
\hline$R O A$ & & $\begin{array}{c}-0.033 \\
(-1.463)\end{array}$ & $\begin{array}{c}-0.008 \\
(-0.200)\end{array}$ & $\begin{array}{c}0.008 \\
(0.217)\end{array}$ & $\begin{array}{l}-0.038^{*} \\
(-1.684)\end{array}$ & $\begin{array}{c}-0.008 \\
(-0.356)\end{array}$ \\
\hline MTB & & $\begin{array}{c}-0.003^{* * *} \\
(-6.319)\end{array}$ & $\begin{array}{c}-0.003^{* * *} \\
(-3.971)\end{array}$ & $\begin{array}{l}-0.001^{*} \\
(-1.793)\end{array}$ & $\begin{array}{c}-0.003^{* * *} \\
(-6.064)\end{array}$ & $\begin{array}{c}-0.003^{* * *} \\
(-5.864)\end{array}$ \\
\hline Sales Growth & & $\begin{array}{l}-0.068^{* * *} \\
(-14.502)\end{array}$ & $\begin{array}{c}-0.066^{* * *} \\
(-6.082)\end{array}$ & $\begin{array}{c}-0.076^{* * *} \\
(-8.811)\end{array}$ & $\begin{array}{l}-0.067^{* * *} \\
(-14.503)\end{array}$ & $\begin{array}{l}-0.068^{* * *} \\
(-14.609)\end{array}$ \\
\hline Sales Volatility & & $\begin{array}{c}0.035^{* * *} \\
(6.227)\end{array}$ & $\begin{array}{c}0.021^{*} \\
(1.858)\end{array}$ & $\begin{array}{l}0.026^{* *} \\
(2.075)\end{array}$ & $\begin{array}{c}0.038^{* * *} \\
(6.672)\end{array}$ & $\begin{array}{c}0.036^{* * *} \\
(6.412)\end{array}$ \\
\hline Age & & $\begin{array}{c}0.007^{* * *} \\
(2.750) \\
\end{array}$ & $\begin{array}{c}0.004 \\
(0.957) \\
\end{array}$ & $\begin{array}{c}0.010^{* * *} \\
(2.678) \\
\end{array}$ & $\begin{array}{l}0.005^{* *} \\
(2.252)\end{array}$ & $\begin{array}{l}0.006^{* *} \\
(2.525)\end{array}$ \\
\hline Industry FE? & & YES & YES & YES & YES & YES \\
\hline Year FE? & & YES & YES & YES & YES & YES \\
\hline Observations & & 32,591 & 8,963 & 11,530 & 32,702 & 32,434 \\
\hline Adj. R-squared & & 0.096 & 0.093 & 0.101 & 0.095 & 0.098 \\
\hline
\end{tabular}

This table presents the results of estimating equation 1 via OLS with Cash ETR as the dependent variable, where Cash ETR is measured as cash taxes paid divided by pre-tax income adjusted for special items. Each column employs a different IIQ proxy (EA Speed, MF Acc, No MW, Analyst Following, AF Acc). IIQ proxies are ranked into quintiles each year and scaled to range from 0 (bottom quintile) to 1 (top quintile). All other variables are defined in the appendix. Coefficients are presented with t-statistics based on firm-clustered standard errors in parenthesis. $* * *, * *$ and $*$ denote significance at a 1,5 , and 10 percent level, for one-tailed tests where there are predictions and two-tailed tests otherwise. 


\section{TABLE 3: INTERNAL INFORMATION QUALITY, COORDINATION, AND TAX AVOIDANCE}

Panel A: Geographic Segment Dispersion

\begin{tabular}{lcccccc}
\hline & $\begin{array}{c}\text { IIQ Proxy: } \\
\text { Dep Var: }\end{array}$ & $\begin{array}{c}\text { EA Speed } \\
\text { Cash ETR }\end{array}$ & $\begin{array}{c}\text { MF Acc } \\
\text { Cash ETR }\end{array}$ & $\begin{array}{c}\text { No MW } \\
\text { Cash ETR }\end{array}$ & $\begin{array}{c}\text { Analyst Foll } \\
\text { Cash ETR }\end{array}$ & $\begin{array}{c}\text { AF Acc } \\
\text { Cash ETR }\end{array}$ \\
\hline VARIABLES & Pred Sign & & & & & \\
\hline IIQ & - & -0.002 & $-0.018^{* *}$ & $-0.023^{*}$ & -0.003 & $-0.016^{* * *}$ \\
& & $(-0.274)$ & $(-1.698)$ & $(-1.428)$ & $(-0.327)$ & $(-2.512)$ \\
Geographic Dispersion & + & $0.114^{* * *}$ & $0.110^{* * *}$ & $0.149^{* * *}$ & $0.101^{* * *}$ & $0.122^{* * *}$ \\
& & $(7.295)$ & $(4.681)$ & $(3.638)$ & $(6.603)$ & $(7.287)$ \\
Info Quality * & - & $-0.101^{* * *}$ & $-0.064^{* *}$ & $-0.075^{* *}$ & $-0.082^{* * *}$ & $-0.111^{* * *}$ \\
Geographic Dispersion & & $(-5.369)$ & $(-2.287)$ & $(-1.825)$ & $(-4.435)$ & $(-5.778)$ \\
\hline Control Variables? & & YES & YES & YES & YES & YES \\
Industry FE? & & YES & YES & YES & YES & YES \\
Year FE? & & YES & YES & YES & YES & YES \\
\hline Observations & & 29,843 & 7,978 & 10,322 & 29,938 & 29,707 \\
Adj. R-squared & & 0.097 & 0.097 & 0.104 & 0.096 & 0.100 \\
\hline
\end{tabular}

Panel B: Business Segment Dispersion

\begin{tabular}{|c|c|c|c|c|c|c|}
\hline & $\begin{array}{l}\text { IIQ Proxy: } \\
\text { Dep Var: }\end{array}$ & $\begin{array}{l}\text { EA Speed } \\
\text { Cash ETR }\end{array}$ & $\begin{array}{c}\text { MF Acc } \\
\text { Cash ETR }\end{array}$ & $\begin{array}{c}\text { No MW } \\
\text { Cash ETR }\end{array}$ & $\begin{array}{l}\text { Analyst Foll } \\
\text { Cash ETR }\end{array}$ & $\begin{array}{c}\text { AF Acc } \\
\text { Cash ETR }\end{array}$ \\
\hline VARIABLES & Pred Sign & & & & & \\
\hline$I I Q$ & - & $\begin{array}{c}-0.018^{* * *} \\
(-2.837)\end{array}$ & $\begin{array}{c}-0.027^{* * *} \\
(-2.908)\end{array}$ & $\begin{array}{l}-0.033^{* *} \\
(-2.101)\end{array}$ & $\begin{array}{l}-0.014^{* *} \\
(-1.857)\end{array}$ & $\begin{array}{l}-0.029^{* * *} \\
(-4.718)\end{array}$ \\
\hline Business Dispersion & + & $\begin{array}{l}0.018^{*} \\
(1.445)\end{array}$ & $\begin{array}{c}0.008 \\
(0.465)\end{array}$ & $\begin{array}{c}0.052 \\
(1.246)\end{array}$ & $\begin{array}{l}0.026^{* *} \\
(2.095)\end{array}$ & $\begin{array}{l}0.036^{* * *} \\
(2.562)\end{array}$ \\
\hline $\begin{array}{l}\text { Info Quality * } \\
\text { Business Dispersion }\end{array}$ & - & $\begin{array}{c}-0.015 \\
(-0.892) \\
\end{array}$ & $\begin{array}{c}-0.026 \\
(-1.161) \\
\end{array}$ & $\begin{array}{c}-0.052 \\
(-1.248) \\
\end{array}$ & $\begin{array}{l}-0.029^{* *} \\
(-1.752)\end{array}$ & $\begin{array}{l}-0.043^{* * *} \\
(-2.486)\end{array}$ \\
\hline Control Variables? & & YES & YES & YES & YES & YES \\
\hline Industry FE? & & YES & YES & YES & YES & YES \\
\hline Year FE? & & YES & YES & YES & YES & YES \\
\hline Observations & & 30,796 & 8,192 & 10,466 & 30,900 & 30,645 \\
\hline Adj. R-squared & & 0.099 & 0.096 & 0.103 & 0.099 & 0.102 \\
\hline \multicolumn{7}{|c|}{$\begin{array}{l}\text { This table presents the results of estimating equation } 2 \text { via OLS with Cash ETR as the dependent variable, where } \\
\text { Cash ETR is measured as cash taxes paid divided by pre-tax income adjusted for special items. Panel A (B) uses } \\
\text { Geographic Dispersion (Business Dispersion) as the segment dispersion proxy, where segment dispersion is the sum } \\
\text { of the squares of (segment sales / total firm sales) minus } 1 \text { then times }-1 \text {. Each column employs a different IIQ proxy } \\
\text { (EA Speed, MF Acc, No MW, Analyst Following, AF Acc). IIQ proxies are ranked into quintiles each year and scaled } \\
\text { to range from } 0 \text { (bottom quintile) to } 1 \text { (top quintile). All other variables are defined in the appendix. Coefficients are } \\
\text { presented with t-statistics based on firm-clustered standard errors in parenthesis. ***, ** and * denote significance } \\
\text { at a } 1,5 \text {, and } 10 \text { percent level, for one-tailed tests where there are predictions and two-tailed tests otherwise. }\end{array}$} \\
\hline
\end{tabular}




\section{TABLE 4: INTERNAL INFORMATION QUALITY, UNCERTAINTY, AND TAX AVOIDANCE}

Panel A: Restructuring

\begin{tabular}{lcccccc}
\hline & $\begin{array}{c}\text { IIQ Proxy: } \\
\text { Dep Var: }\end{array}$ & $\begin{array}{c}\text { EA Speed } \\
\text { Cash ETR }\end{array}$ & $\begin{array}{c}\text { MF Acc } \\
\text { Cash ETR }\end{array}$ & $\begin{array}{c}\text { No MW } \\
\text { Cash ETR }\end{array}$ & $\begin{array}{c}\text { Analyst Foll } \\
\text { Cash ETR }\end{array}$ & $\begin{array}{c}\text { AF Acc } \\
\text { Cash ETR }\end{array}$ \\
\hline VARIABLES & Pred Sign & & & & & \\
\hline IIQ & - & $-0.021^{* * *}$ & $-0.027^{* * *}$ & $-0.047^{* * *}$ & $-0.018^{* * *}$ & $-0.033^{* * *}$ \\
& & $(-3.918)$ & $(-3.619)$ & $(-3.652)$ & $(-2.808)$ & $(-6.452)$ \\
Restructure & + & $0.015^{* *}$ & $0.020^{* *}$ & 0.011 & $0.012^{*}$ & $0.024^{* * *}$ \\
& & $(1.744)$ & $(1.926)$ & $(0.478)$ & $(1.470)$ & $(2.598)$ \\
Info Quality $*$ & - & $-0.025^{* *}$ & $-0.029^{* *}$ & -0.015 & $-0.023^{* *}$ & $-0.044^{* * *}$ \\
$\quad$ Restructure & & $(-2.130)$ & $(-2.107)$ & $(-0.624)$ & $(-2.072)$ & $(-3.717)$ \\
\hline Control Variables? & & YES & YES & YES & YES & YES \\
Industry FE? & & YES & YES & YES & YES & YES \\
Year FE? & & YES & YES & YES & YES & YES \\
\hline Observations & & 32,591 & 8,963 & 11,530 & 32,702 & 32,434 \\
Adj. R-squared & & 0.099 & 0.103 & 0.108 & 0.098 & 0.101 \\
\hline
\end{tabular}

Panel B: Sales Volatility

\begin{tabular}{lcccccc}
\hline & $\begin{array}{c}\text { IIQ Proxy: } \\
\text { Dep Var: }\end{array}$ & $\begin{array}{c}\text { EA Speed } \\
\text { Cash ETR }\end{array}$ & $\begin{array}{c}\text { MF Acc } \\
\text { Cash ETR }\end{array}$ & $\begin{array}{c}\text { No MW } \\
\text { Cash ETR }\end{array}$ & $\begin{array}{c}\text { Analyst Foll } \\
\text { Cash ETR }\end{array}$ & $\begin{array}{c}\text { AF Acc } \\
\text { Cash ETR }\end{array}$ \\
\hline VARIABLES & Pred Sign & & & & & \\
\hline IIQ & - & $-0.018^{* * *}$ & $-0.034^{* * *}$ & $-0.050^{* * *}$ & $-0.012^{*}$ & $-0.027^{* * *}$ \\
Sales Volatility & & $(-2.679)$ & $(-3.668)$ & $(-3.190)$ & $(-1.551)$ & $(-4.030)$ \\
& + & $0.047^{* * *}$ & $0.023^{*}$ & 0.035 & $0.058^{* * *}$ & $0.063^{* * *}$ \\
Info Quality & & $(5.191)$ & $(1.361)$ & $(0.963)$ & $(5.862)$ & $(5.693)$ \\
Sales Volatility & - & $-0.025^{* *}$ & -0.005 & -0.010 & $-0.036^{* * *}$ & $-0.045^{* * *}$ \\
\hline Control Variables? & & $(-1.921)$ & $(-0.213)$ & $(-0.261)$ & $(-2.736)$ & $(-3.291)$ \\
Industry FE? & & YES & YES & YES & YES & YES \\
Year FE? & & YES & YES & YES & YES & YES \\
\hline Observations & & YES & YES & YES & YES & YES \\
Adj. R-squared & & 32,591 & 8,963 & 11,530 & 32,702 & 32,434 \\
This & & 0.096 & 0.093 & 0.101 & 0.095 & 0.098 \\
\hline
\end{tabular}

This table presents the results of estimating equation 3 via OLS with Cash ETR as the dependent variable, where Cash ETR is measured as cash taxes paid divided by pre-tax income adjusted for special items. Panel A (B) uses Restructure (Sales Volatility) as the uncertainty proxy, where Restructure is an indicator variable equal to 1 if the firm reports a restructuring charge that year and zero otherwise, and Sales Volatility is the standard deviation of sales over the current five year period scaled by median total assets over the same period. Each column employs a different IIQ proxy (EA Speed, MF Acc, No MW, Analyst Following, AF Acc). IIQ proxies are ranked into quintiles each year and scaled to range from 0 (bottom quintile) to 1 (top quintile). All other variables are defined in the appendix. Coefficients are presented with t-statistics based on firm-clustered standard errors in parenthesis. ***, ** and $*$ denote significance at a 1,5 , and 10 percent level, for one-tailed tests where there are predictions and twotailed tests otherwise. 
TABLE 5: INTERNAL INFORMATION QUALITY AND BUDGETED TAX RISK

\begin{tabular}{|c|c|c|c|c|c|c|}
\hline VARIABLES & $\begin{array}{l}\text { IIQ Proxy: } \\
\text { Dep Var: }\end{array}$ & $\begin{array}{c}\text { EA Speed } \\
\text { UTB }\end{array}$ & $\begin{array}{c}\text { MF Acc } \\
\text { UTB }\end{array}$ & $\begin{array}{c}\text { No MW } \\
\text { UTB }\end{array}$ & $\begin{array}{c}\text { Analyst Foll } \\
\text { UTB }\end{array}$ & $\begin{array}{c}A F A c c \\
U T B\end{array}$ \\
\hline \multirow[t]{2}{*}{$I I Q$} & Pred & 0.002 & -0.001 & -0.001 & $-0.003^{* *}$ & $-0.002^{* *}$ \\
\hline & Sign: - & (1.409) & $(-0.802)$ & $(-0.461)$ & $(-2.184)$ & $(-2.144)$ \\
\hline \multirow[t]{2}{*}{ Size } & & $0.001^{*}$ & $0.002^{* * *}$ & $0.001^{* *}$ & $0.001^{* * *}$ & $0.001^{* * *}$ \\
\hline & & $(1.768)$ & (3.048) & $(2.260)$ & (3.174) & $(3.279)$ \\
\hline \multirow[t]{2}{*}{ PPE } & & $-0.017^{* * *}$ & $-0.023^{* * *}$ & $-0.018^{* * *}$ & $-0.017^{* * *}$ & $-0.017^{* * *}$ \\
\hline & & $(-5.398)$ & $(-4.627)$ & $(-5.598)$ & $(-5.340)$ & $(-5.313)$ \\
\hline \multirow[t]{2}{*}{$\triangle P P E$} & & -0.007 & 0.011 & -0.003 & -0.007 & -0.007 \\
\hline & & $(-1.393)$ & (1.207) & $(-0.647)$ & $(-1.377)$ & $(-1.308)$ \\
\hline \multirow[t]{2}{*}{ Leverage } & & $0.007^{*}$ & $0.012^{* *}$ & $0.007^{* *}$ & 0.006 & 0.005 \\
\hline & & $(1.930)$ & $(2.310)$ & (1.985) & $(1.594)$ & $(1.427)$ \\
\hline \multirow{2}{*}{ Intangibles } & & $-0.011^{* * *}$ & $-0.016^{* * *}$ & $-0.012^{* * *}$ & $-0.011^{* * *}$ & $-0.012^{* * *}$ \\
\hline & & $(-3.916)$ & $(-3.575)$ & $(-4.295)$ & $(-3.553)$ & $(-3.854)$ \\
\hline \multirow[t]{2}{*}{ RED Expense } & & $0.061^{* * *}$ & $0.080^{* * *}$ & $0.065^{* * *}$ & $0.066^{* * *}$ & $0.063^{* * *}$ \\
\hline & & $(5.840)$ & $(5.227)$ & $(5.468)$ & $(6.005)$ & $(6.229)$ \\
\hline \multirow[t]{2}{*}{ NOL Dummy } & & $0.001^{*}$ & -0.000 & 0.001 & $0.001^{*}$ & $0.001^{*}$ \\
\hline & & $(1.838)$ & $(-0.171)$ & (1.317) & (1.899) & $(1.680)$ \\
\hline \multirow[t]{2}{*}{$\triangle N O L$} & & 0.003 & -0.002 & 0.004 & 0.003 & 0.003 \\
\hline & & $(1.100)$ & $(-0.236)$ & $(1.168)$ & (1.003) & $(0.976)$ \\
\hline \multirow[t]{2}{*}{ Extraordinary Items } & & -0.006 & -0.039 & -0.035 & -0.001 & -0.004 \\
\hline & & $(-0.207)$ & $(-0.844)$ & $(-0.851)$ & $(-0.031)$ & $(-0.129)$ \\
\hline \multirow[t]{2}{*}{ Foreign Income } & & $0.041^{* * *}$ & $0.089^{* * *}$ & $0.043^{* * *}$ & $0.041^{* * *}$ & $0.042^{* * *}$ \\
\hline & & $(3.234)$ & $(4.023)$ & $(3.249)$ & $(3.227)$ & $(3.318)$ \\
\hline \multirow[t]{2}{*}{ FI Dummy } & & $0.003^{* * *}$ & 0.002 & $0.003^{* * *}$ & $0.003^{* * *}$ & $0.003^{* * *}$ \\
\hline & & $(3.163)$ & $(1.185)$ & $(3.024)$ & $(3.017)$ & (3.397) \\
\hline \multirow[t]{2}{*}{$R O A$} & & $0.009^{* *}$ & $0.026^{* * *}$ & 0.007 & $0.011^{* * *}$ & $0.011^{* * *}$ \\
\hline & & (2.095) & $(2.905)$ & $(1.452)$ & $(2.625)$ & $(2.585)$ \\
\hline \multirow[t]{2}{*}{ MTB } & & -0.000 & -0.000 & -0.000 & -0.000 & -0.000 \\
\hline & & $(-1.128)$ & $(-1.470)$ & $(-1.159)$ & $(-0.660)$ & $(-0.811)$ \\
\hline \multirow[t]{2}{*}{ Sales Growth } & & $-0.002^{* *}$ & $-0.007^{* *}$ & $-0.002^{* *}$ & $-0.002^{* *}$ & $-0.002^{* *}$ \\
\hline & & $(-2.234)$ & $(-2.103)$ & $(-2.045)$ & $(-2.278)$ & $(-2.106)$ \\
\hline \multirow[t]{2}{*}{ Sales Volatility } & & 0.002 & -0.002 & 0.003 & 0.002 & 0.001 \\
\hline & & $(0.873)$ & $(-0.677)$ & $(1.105)$ & $(0.853)$ & $(0.458)$ \\
\hline \multirow[t]{2}{*}{ Age } & & $0.001^{* *}$ & $0.003^{* * *}$ & $0.002^{* * *}$ & $0.001^{* *}$ & $0.001^{* *}$ \\
\hline & & $(2.554)$ & $(3.688)$ & $(2.785)$ & $(2.190)$ & $(2.450)$ \\
\hline Industry FE? & & YES & YES & YES & YES & YES \\
\hline Year FE? & & YES & YES & YES & YES & YES \\
\hline Observations & & 6,232 & 1,576 & 5,944 & 6,287 & 6,083 \\
\hline Adj. R-squared & & 0.160 & 0.260 & 0.172 & 0.158 & 0.161 \\
\hline
\end{tabular}

This table presents the results of estimating equation 1 via OLS with UTB as the dependent variable, where UTB is measured as the average unrecognized tax benefit scaled by average total assets. Each column employs a different IIQ proxy (EA Speed, MF Acc, No MW, Analyst Following, AF Acc). IIQ proxies are ranked into quintiles each year and scaled to range from 0 (bottom quintile) to 1 (top quintile). All other variables are defined in the appendix. Coefficients are presented with t-statistics based on firm-clustered standard errors in parenthesis. ***, ** and * denote significance at a 1, 5, and 10 percent level, for one-tailed tests where there are predictions and two-tailed tests otherwise. 
TABLE 6: INTERNAL INFORMATION QUALITY AND REALIZED TAX RISK

\begin{tabular}{|c|c|c|c|c|c|c|}
\hline VARIABLES & $\begin{array}{l}\text { IIQ5 Proxy: } \\
\text { Dep Var: }\end{array}$ & $\begin{array}{c}\text { EA Speed } \\
\text { CashETRVol }\end{array}$ & $\begin{array}{c}\text { MF Acc } \\
\text { CashETRVol }\end{array}$ & $\begin{array}{c}\text { No MW } \\
\text { CashETRVol }\end{array}$ & $\begin{array}{l}\text { Analyst Foll } \\
\text { CashETRVol }\end{array}$ & $\begin{array}{c}\text { AF Acc } \\
\text { CashETRVol }\end{array}$ \\
\hline IIQ5 & $\begin{array}{c}\text { Pred } \\
\text { Sign: - }\end{array}$ & $\begin{array}{c}-0.031^{* * *} \\
(-5.159)\end{array}$ & $\begin{array}{c}-0.063^{* * *} \\
(-4.175)\end{array}$ & $\begin{array}{c}-0.068^{* *} \\
(-2.345)\end{array}$ & $\begin{array}{c}-0.015^{* *} \\
(-2.013)\end{array}$ & $\begin{array}{l}-0.105^{* * *} \\
(-12.891)\end{array}$ \\
\hline Size5 & & $\begin{array}{c}-0.004^{* * *} \\
(-3.331)\end{array}$ & $\begin{array}{c}-0.009 * * * \\
(-3.149)\end{array}$ & $\begin{array}{c}-0.006^{* * *} \\
(-2.606)\end{array}$ & $\begin{array}{c}-0.005^{* * *} \\
(-2.817)\end{array}$ & $\begin{array}{c}-0.002 \\
(-1.557)\end{array}$ \\
\hline PPE5 & & $\begin{array}{l}0.028^{* *} \\
(2.093)\end{array}$ & $\begin{array}{c}0.030 \\
(0.978)\end{array}$ & $\begin{array}{c}0.011 \\
(0.425)\end{array}$ & $\begin{array}{c}0.021 \\
(1.583)\end{array}$ & $\begin{array}{c}0.018 \\
(1.374)\end{array}$ \\
\hline$\triangle P P E 5$ & & $\begin{array}{c}-0.075^{* * *} \\
(-8.900)\end{array}$ & $\begin{array}{c}-0.057^{* * *} \\
(-2.815)\end{array}$ & $\begin{array}{l}-0.058^{* * *} \\
(-2.735)\end{array}$ & $\begin{array}{c}-0.070^{* * *} \\
(-8.187)\end{array}$ & $\begin{array}{c}-0.057^{* * *} \\
(-6.861)\end{array}$ \\
\hline Leverage5 & & $\begin{array}{l}0.032^{* *} \\
(2.527)\end{array}$ & $\begin{array}{c}0.035 \\
(1.111)\end{array}$ & $\begin{array}{c}0.035 \\
(1.640)\end{array}$ & $\begin{array}{c}0.036^{* * *} \\
(2.789)\end{array}$ & $\begin{array}{c}0.010 \\
(0.804)\end{array}$ \\
\hline Intangibles5 & & $\begin{array}{c}-0.050^{* * *} \\
(-4.204)\end{array}$ & $\begin{array}{l}-0.058^{* *} \\
(-2.458)\end{array}$ & $\begin{array}{c}-0.087^{* * *} \\
(-4.610)\end{array}$ & $\begin{array}{c}-0.049^{* * *} \\
(-4.106)\end{array}$ & $\begin{array}{c}-0.034^{* * *} \\
(-2.876)\end{array}$ \\
\hline RED Expense5 & & $\begin{array}{c}0.114^{* * *} \\
(4.432)\end{array}$ & $\begin{array}{c}0.018 \\
(0.307)\end{array}$ & $\begin{array}{c}-0.006 \\
(-0.125)\end{array}$ & $\begin{array}{c}0.094^{* * *} \\
(3.634)\end{array}$ & $\begin{array}{c}0.084^{* * *} \\
(3.354)\end{array}$ \\
\hline NOL Dummy5 & & $\begin{array}{c}0.002 \\
(0.625)\end{array}$ & $\begin{array}{c}0.002 \\
(0.405)\end{array}$ & $\begin{array}{c}0.001 \\
(0.190)\end{array}$ & $\begin{array}{c}0.002 \\
(0.743)\end{array}$ & $\begin{array}{c}0.002 \\
(0.638)\end{array}$ \\
\hline$\triangle N O L 5$ & & $\begin{array}{c}0.013 \\
(0.968)\end{array}$ & $\begin{array}{c}0.016 \\
(0.500)\end{array}$ & $\begin{array}{c}-0.002 \\
(-0.089)\end{array}$ & $\begin{array}{c}0.014 \\
(0.985)\end{array}$ & $\begin{array}{c}0.015 \\
(1.106)\end{array}$ \\
\hline Extraordinary Items5 & & $\begin{array}{c}0.702^{* * *} \\
(3.486)\end{array}$ & $\begin{array}{l}1.273^{* *} \\
(2.334)\end{array}$ & $\begin{array}{l}1.025^{* *} \\
(1.985)\end{array}$ & $\begin{array}{c}0.681^{* * *} \\
(3.378)\end{array}$ & $\begin{array}{c}0.760^{* * *} \\
(3.878)\end{array}$ \\
\hline Foreign Income5 & & $\begin{array}{c}-0.220^{* * *} \\
(-3.443)\end{array}$ & $\begin{array}{l}-0.234^{*} \\
(-1.855)\end{array}$ & $\begin{array}{c}-0.393^{* * *} \\
(-3.815)\end{array}$ & $\begin{array}{c}-0.213^{* * *} \\
(-3.285)\end{array}$ & $\begin{array}{c}-0.200^{* * *} \\
(-3.149)\end{array}$ \\
\hline FI Dummy5 & & $\begin{array}{c}0.015^{* * *} \\
(3.662)\end{array}$ & $\begin{array}{c}0.011 \\
(1.326)\end{array}$ & $\begin{array}{c}0.009 \\
(1.243)\end{array}$ & $\begin{array}{c}0.014^{* * *} \\
(3.547)\end{array}$ & $\begin{array}{c}0.014^{* * *} \\
(3.593)\end{array}$ \\
\hline ROA5 & & $\begin{array}{l}-0.425^{* * *} \\
(-16.428)\end{array}$ & $\begin{array}{c}-0.404^{* * *} \\
(-6.728)\end{array}$ & $\begin{array}{c}-0.426^{* * *} \\
(-9.933)\end{array}$ & $\begin{array}{l}-0.430^{* * *} \\
(-16.548)\end{array}$ & $\begin{array}{l}-0.355^{* * *} \\
(-13.779)\end{array}$ \\
\hline MTB5 & & $\begin{array}{c}-0.000 \\
(-0.648)\end{array}$ & $\begin{array}{c}0.000 \\
(0.215)\end{array}$ & $\begin{array}{c}-0.000 \\
(-0.075)\end{array}$ & $\begin{array}{c}-0.000 \\
(-0.808)\end{array}$ & $\begin{array}{c}0.000 \\
(0.778)\end{array}$ \\
\hline Sales Growth5 & & $\begin{array}{l}-0.001^{* *} \\
(-2.096)\end{array}$ & $\begin{array}{c}-0.001 \\
(-0.289)\end{array}$ & $\begin{array}{l}-0.003^{* *} \\
(-2.036)\end{array}$ & $\begin{array}{l}-0.001^{*} \\
(-1.943)\end{array}$ & $\begin{array}{c}-0.001 \\
(-1.614)\end{array}$ \\
\hline Sales Volatility & & $\begin{array}{c}0.038^{* * *} \\
(5.916)\end{array}$ & $\begin{array}{c}0.014 \\
(0.916)\end{array}$ & $\begin{array}{l}0.040^{*} \\
(1.865)\end{array}$ & $\begin{array}{c}0.038^{* * *} \\
(6.008)\end{array}$ & $\begin{array}{c}0.036^{* * *} \\
(6.089)\end{array}$ \\
\hline Age5 & & $\begin{array}{c}-0.000 \\
(-0.194) \\
\end{array}$ & $\begin{array}{l}0.008^{*} \\
(1.648)\end{array}$ & $\begin{array}{c}-0.000 \\
(-0.024) \\
\end{array}$ & $\begin{array}{c}-0.001 \\
(-0.512) \\
\end{array}$ & $\begin{array}{c}-0.001 \\
(-0.610) \\
\end{array}$ \\
\hline Industry FE? & & YES & YES & YES & YES & YES \\
\hline Year FE? & & YES & YES & YES & YES & YES \\
\hline $\begin{array}{l}\text { Observations } \\
\text { Adj. R-squared }\end{array}$ & & $\begin{array}{c}14,543 \\
0.166\end{array}$ & $\begin{array}{l}2,332 \\
0.204\end{array}$ & $\begin{array}{l}2,938 \\
0.173\end{array}$ & $\begin{array}{c}14,543 \\
0.161\end{array}$ & $\begin{array}{c}14,472 \\
0.193\end{array}$ \\
\hline
\end{tabular}

This table presents the results of estimating equation 1 via OLS with Cash ETR Volatility as the dependent variable, where Cash ETR Volatility is measured as the standard deviation of Cash ETR over the current five year period. Each column employs a different IIQ proxy (EA Speed, MF Acc, No MW, Analyst Following, AF Acc). IIQ proxies are ranked into quintiles each year and scaled to range from 0 (bottom quintile) to 1 (top quintile), and then are averaged over the current five year period. All other variables are defined in the appendix, and are measured over the current five year period. Coefficients are presented with t-statistics based on firm-clustered standard errors in parenthesis. $* * *, * *$ and $*$ denote significance at a 1,5 , and 10 percent level, for one-tailed tests where there are predictions and two-tailed tests otherwise. 
TABLE 7: IIQ AND LONG-RUN TAX AVOIDANCE

\begin{tabular}{|c|c|c|c|c|c|c|}
\hline VARIABLES & $\begin{array}{l}\text { IIQ5 Proxy: } \\
\text { Dep Var: }\end{array}$ & $\begin{array}{c}\text { EA Speed } \\
\text { Cash ETR5 }\end{array}$ & $\begin{array}{c}\text { MF Acc } \\
\text { Cash ETR5 }\end{array}$ & $\begin{array}{c}\text { No MW } \\
\text { Cash ETR5 }\end{array}$ & $\begin{array}{c}\text { Analyst Foll } \\
\text { Cash ETR5 }\end{array}$ & $\begin{array}{c}\text { AF Acc } \\
\text { Cash ETR5 }\end{array}$ \\
\hline IIQ5 & $\begin{array}{c}\text { Pred } \\
\text { Sign: - }\end{array}$ & $\begin{array}{c}-0.039^{* * *} \\
(-4.123)\end{array}$ & $\begin{array}{l}-0.050^{* *} \\
(-2.094)\end{array}$ & $\begin{array}{l}-0.074^{* *} \\
(-2.088)\end{array}$ & $\begin{array}{c}-0.053^{* * *} \\
(-4.471)\end{array}$ & $\begin{array}{c}-0.095^{* * *} \\
(-6.855)\end{array}$ \\
\hline Size5 & & $\begin{array}{l}-0.005^{* *} \\
(-2.309)\end{array}$ & $\begin{array}{l}-0.009^{* *} \\
(-2.224)\end{array}$ & $\begin{array}{c}-0.003 \\
(-0.965)\end{array}$ & $\begin{array}{c}-0.000 \\
(-0.048)\end{array}$ & $\begin{array}{l}-0.003^{*} \\
(-1.661)\end{array}$ \\
\hline PPE5 & & $\begin{array}{c}-0.030 \\
(-1.387)\end{array}$ & $\begin{array}{c}-0.063 \\
(-1.245)\end{array}$ & $\begin{array}{c}0.025 \\
(0.542)\end{array}$ & $\begin{array}{l}-0.039^{*} \\
(-1.807)\end{array}$ & $\begin{array}{l}-0.045^{* *} \\
(-2.049)\end{array}$ \\
\hline$\triangle P P E 5$ & & $\begin{array}{c}-0.096^{* * *} \\
(-7.036)\end{array}$ & $\begin{array}{l}-0.095^{* *} \\
(-2.346)\end{array}$ & $\begin{array}{c}-0.148^{* * *} \\
(-4.464)\end{array}$ & $\begin{array}{c}-0.088^{* * *} \\
(-6.467)\end{array}$ & $\begin{array}{c}-0.078^{* * *} \\
(-5.713)\end{array}$ \\
\hline Leverage5 & & $\begin{array}{c}-0.089^{* * *} \\
(-3.688)\end{array}$ & $\begin{array}{c}-0.011 \\
(-0.164)\end{array}$ & $\begin{array}{c}-0.052 \\
(-1.342)\end{array}$ & $\begin{array}{c}-0.089^{* * *} \\
(-3.817)\end{array}$ & $\begin{array}{c}-0.109^{* * *} \\
(-4.606)\end{array}$ \\
\hline Intangibles5 & & $\begin{array}{c}-0.000 \\
(-0.017)\end{array}$ & $\begin{array}{c}-0.033 \\
(-0.843)\end{array}$ & $\begin{array}{c}0.011 \\
(0.376)\end{array}$ & $\begin{array}{c}0.003 \\
(0.176)\end{array}$ & $\begin{array}{c}0.018 \\
(0.935)\end{array}$ \\
\hline RED Expense5 & & $\begin{array}{l}-0.094^{* *} \\
(-2.184)\end{array}$ & $\begin{array}{c}0.001 \\
(0.006)\end{array}$ & $\begin{array}{l}-0.159^{* *} \\
(-2.065)\end{array}$ & $\begin{array}{l}-0.103^{* *} \\
(-2.472)\end{array}$ & $\begin{array}{c}-0.127^{* * *} \\
(-3.030)\end{array}$ \\
\hline NOL Dummy5 & & $\begin{array}{c}-0.028^{* * *} \\
(-5.527)\end{array}$ & $\begin{array}{c}-0.009 \\
(-1.107)\end{array}$ & $\begin{array}{c}-0.029^{* * *} \\
(-3.381)\end{array}$ & $\begin{array}{c}-0.028^{* * *} \\
(-5.445)\end{array}$ & $\begin{array}{c}-0.029^{* * *} \\
(-5.619)\end{array}$ \\
\hline$\triangle N O L 5$ & & $\begin{array}{c}0.027 \\
(1.384)\end{array}$ & $\begin{array}{c}0.044 \\
(0.792)\end{array}$ & $\begin{array}{c}0.048 \\
(1.307)\end{array}$ & $\begin{array}{c}0.030 \\
(1.510)\end{array}$ & $\begin{array}{c}0.025 \\
(1.268)\end{array}$ \\
\hline Extraordinary Items5 & & $\begin{array}{c}1.856^{* * *} \\
(6.072)\end{array}$ & $\begin{array}{c}2.618^{* * *} \\
(3.783)\end{array}$ & $\begin{array}{c}3.553^{* * *} \\
(4.212)\end{array}$ & $\begin{array}{c}1.852^{* * *} \\
(6.053)\end{array}$ & $\begin{array}{c}1.883^{* * *} \\
(6.022)\end{array}$ \\
\hline Foreign Income5 & & $\begin{array}{c}-0.091 \\
(-0.818)\end{array}$ & $\begin{array}{c}-0.236 \\
(-1.279)\end{array}$ & $\begin{array}{l}-0.376^{* *} \\
(-2.190)\end{array}$ & $\begin{array}{c}-0.094 \\
(-0.838)\end{array}$ & $\begin{array}{c}-0.040 \\
(-0.361)\end{array}$ \\
\hline FI Dummy5 & & $\begin{array}{c}0.010 \\
(1.579)\end{array}$ & $\begin{array}{c}0.015 \\
(1.252)\end{array}$ & $\begin{array}{c}0.017 \\
(1.467)\end{array}$ & $\begin{array}{c}0.009 \\
(1.459)\end{array}$ & $\begin{array}{c}0.008 \\
(1.267)\end{array}$ \\
\hline ROA5 & & $\begin{array}{c}-0.146^{* * *} \\
(-3.595)\end{array}$ & $\begin{array}{c}0.077 \\
(0.869)\end{array}$ & $\begin{array}{l}-0.115 \\
(-1.466)\end{array}$ & $\begin{array}{c}-0.136^{* * *} \\
(-3.328)\end{array}$ & $\begin{array}{c}-0.066 \\
(-1.600)\end{array}$ \\
\hline MTB5 & & $\begin{array}{c}-0.003^{* * *} \\
(-2.808)\end{array}$ & $\begin{array}{l}-0.003^{* *} \\
(-2.116)\end{array}$ & $\begin{array}{c}-0.002 \\
(-1.136)\end{array}$ & $\begin{array}{l}-0.002^{* *} \\
(-2.453)\end{array}$ & $\begin{array}{l}-0.002^{* *} \\
(-2.142)\end{array}$ \\
\hline Sales Growth5 & & $\begin{array}{c}-0.005^{* * *} \\
(-5.564)\end{array}$ & $\begin{array}{c}-0.005 \\
(-1.568)\end{array}$ & $\begin{array}{c}-0.006^{* * *} \\
(-3.035)\end{array}$ & $\begin{array}{c}-0.005^{* * *} \\
(-5.497)\end{array}$ & $\begin{array}{c}-0.005^{* * *} \\
(-5.305)\end{array}$ \\
\hline Sales Volatility & & $\begin{array}{c}0.032^{* * *} \\
(3.410)\end{array}$ & $\begin{array}{c}0.020 \\
(0.807)\end{array}$ & $\begin{array}{c}0.089^{* * *} \\
(3.049)\end{array}$ & $\begin{array}{c}0.032^{* * *} \\
(3.511)\end{array}$ & $\begin{array}{c}0.028^{* * *} \\
(3.108)\end{array}$ \\
\hline Age5 & & $\begin{array}{c}0.002 \\
(0.533) \\
\end{array}$ & $\begin{array}{c}0.008 \\
(1.264) \\
\end{array}$ & $\begin{array}{c}0.001 \\
(0.169) \\
\end{array}$ & $\begin{array}{c}-0.001 \\
(-0.264) \\
\end{array}$ & $\begin{array}{c}0.002 \\
(0.545)\end{array}$ \\
\hline Industry FE? & & $\begin{array}{l}\text { YES } \\
\text { YES }\end{array}$ & $\begin{array}{l}\text { YES } \\
\text { YES }\end{array}$ & $\begin{array}{l}\text { YES } \\
\text { YES }\end{array}$ & $\begin{array}{l}\text { YES } \\
\text { YFS }\end{array}$ & $\begin{array}{l}\text { YES } \\
\text { YFS }\end{array}$ \\
\hline Year FE? & & $\begin{array}{c}\text { YES } \\
18751\end{array}$ & $\frac{\text { YES }}{2.490}$ & $\frac{\text { YES }}{37705}$ & $\begin{array}{c}\text { YES } \\
18.751\end{array}$ & $\begin{array}{c}\text { YES } \\
18,594\end{array}$ \\
\hline $\begin{array}{l}\text { Observations } \\
\text { Adj. R-squared }\end{array}$ & & $\begin{array}{c}18,751 \\
0.119 \\
\end{array}$ & $\begin{array}{l}2,490 \\
0.163 \\
\end{array}$ & $\begin{array}{l}3,705 \\
0.165 \\
\end{array}$ & $\begin{array}{c}18,751 \\
0.119 \\
\end{array}$ & $\begin{array}{c}18,594 \\
0.125 \\
\end{array}$ \\
\hline
\end{tabular}

This table presents the results of estimating equation 1 via OLS with Cash ETR5 as the dependent variable, where Cash ETR5 is measured as cash taxes paid over the current five year period scaled by pre-tax income adjusted for special items over the same period. Each column employs a different IIQ proxy (EA Speed, MF Acc, No MW, Analyst Following, AF Acc). IIQ proxies are ranked into quintiles each year and scaled to range from 0 (bottom quintile) to 1 (top quintile), and then are averaged over the current five year period. All other variables are defined in the appendix, and are measured over the current five year period. Coefficients are presented with t-statistics based on firm-clustered standard errors in parenthesis. $* * * * *$ and $*$ denote significance at a 1,5 , and 10 percent level, for one-tailed tests where there are predictions and two-tailed tests otherwise. 
TABLE 8: CHANGES IN INTERNAL INFORMATION QUALITY AND TAX AVOIDANCE

\begin{tabular}{lcccccc}
\hline & $\Delta I I Q$ & & & \multicolumn{3}{c}{$\Delta$ Analyst } \\
& Proxy: & $\Delta$ EA Speed & $\Delta$ MF Acc & $\Delta$ No MW & Foll & $\Delta$ AF Acc \\
VARIABLES & Dep Var: & $\Delta$ Cash ETR & $\Delta$ Cash ETR & $\Delta$ Cash ETR & $\Delta$ Cash ETR & $\Delta$ Cash ETR \\
\hline$\Delta I I Q$ & Pred & $-0.037^{* * *}$ & $-0.015^{* *}$ & -0.014 & -0.009 & $-0.045^{* * *}$ \\
& Sign: - & $(-4.227)$ & $(-1.952)$ & $(-1.039)$ & $(-0.912)$ & $(-8.390)$ \\
\hline Control Variables? & & YES & YES & YES & YES & YES \\
Industry FE? & & YES & YES & YES & YES & YES \\
Year FE? & YES & YES & YES & YES & YES \\
\hline Observations & 25,760 & 5,856 & 8,489 & 25,848 & 25,622 \\
Adj. R-squared & & 0.062 & 0.056 & 0.061 & 0.062 & 0.066 \\
\hline
\end{tabular}

This table presents the results of estimating a first-differenced version of equation 1 via OLS with $\triangle$ Cash ETR as the dependent variable, where $\triangle$ Cash ETR is measured as the change in the cash effective tax rate in the current year minus the cash effective tax rate in the previous year. Each column employs a change in a different $\triangle \mathrm{IIQ}$ proxy ( $\triangle E A$ Speed, $\triangle M F$ Acc, $\triangle N o M W, \triangle$ Analyst Following, $\triangle A F$ Acc). IIQ proxies are ranked into quintiles each year and scaled to range from 0 (bottom quintile) to 1 (top quintile), and are measured as the ranked value from this year minus the ranked value in the previous year. All other variables are defined in the appendix, and are also measured as the change in the variable from the prior year to the current year. Coefficients are presented with t-statistics based on firm-clustered standard errors in parenthesis. ${ }^{* * *}, * *$ and $*$ denote significance at a 1,5 , and 10 percent level, for one-tailed tests where there are predictions and two-tailed tests otherwise. 